\title{
High FrEQUENCY TRADING AND END-OF-DAY MANIPULATION*
}

\author{
Douglas Cumming \\ York University - Schulich School of Business \\ 4700 Keele Street \\ Toronto, Ontario M3J 1P3 \\ Canada \\ http://ssrn.com/author $=75390$ \\ douglas.cumming@gmail.com
}

\author{
Feng Zhan \\ York University - Schulich School of Business \\ 4700 Keele Street \\ Toronto, Ontario M3J 1P3 \\ Canada \\ http://www.schulich.yorku.ca/ \\ fzhan09@schulich.yorku.ca
}

\author{
Michael Aitken \\ Australian School of Business \\ University of New South Wales \\ Sydney NSW 2052 Australia \\ http://ssrn.com/author=49920 \\ m.aitken@,cmcrc.com
}

First draft: 30 March 2012

This Draft: 08 November 2012

\begin{abstract}
* We are indebted to the UK Government Office for Science, the Investment Industry Regulatory Organization of Canada (IIROC) and Capital Markets CRC for financial support. We owe special thanks to Sofia Johan and three anonymous referees from the UK Government Office for Science for helpful comments and suggestions. Sofia Johan generously gave permission to use data on surveillance from Cumming and Johan (2008). Also, we owe thanks to the seminar participants at York (Toronto), CEIBS (Shanghai), Bank of Canada and FMA. This paper will be presented at AEA (2013).
\end{abstract}




\title{
High FREQUENCY TRADING AND END-OF-DAY MANIPULATION
}

\begin{abstract}
We examine the impact of high frequency trading on the frequency and severity of suspected end of day price dislocation cases in 22 stock exchanges around the world over the period January 2003 - June 2011. Controlling for country, market, legal and other differences across exchanges and over time, and using a variety of robustness checks, we show that the presence of high frequency trading in some markets has significantly mitigated the frequency and severity of end-of-day manipulation, counter to recent concerns expressed in the media. The effect of HFT is more pronounced than the role of trading rules, surveillance, enforcement and legal conditions in curtailing the frequency and severity of end-of-day manipulation. We show our findings are robust to different measures of end-of-day manipulation, including but not limited to option expiry dates, among other things.
\end{abstract}

Keywords: High frequency trading, End-of-day Manipulation, Trading Rules, Surveillance, Law and Finance

JEL Codes: G12, G14, G18, K22 
"There is nothing so terrible as activity without insight."

- Johann Wolfgang von Goethe

\section{Introduction}

High frequency trading (HFT) has become commonplace in many exchanges around the world. HFT involves implementing proprietary trading strategies through the use computerized algorithms. HFTs rapidly trade in and out of positions thousands of times a day without holding positions at the end of the day, and profit by competing for consistent albeit small profits on each trade. While estimates vary due to the difficulty in ascertaining whether each trade is an HFT, recent estimates suggest HFT accounts for $50-70 \%$ of equity trades in the U.S., $40 \%$ in Canada, and 35\% in London (Chang, 2010 ; Grant, 2011 ; O'Reilly, 2012). The growth in HFT activities has generated plenty of attention from financial market regulators and commentators, ${ }^{1}$ particularly as HFTs were found to have contributed to the May 6, 2010 Flash Crash by withdrawing liquidity (Easley et al., 2010). Some commentators have likewise expressed concern that HFT might increase the prevalence of market manipulation (Biasis and Woolley, 2011). However, prior work has not empirically examined the impact of HFT on specific forms of manipulation.

\footnotetext{
${ }^{1}$ See, e.g., Huw Jones, "EU Lawmaker Turns Screws on Ultra-Fast Trading”, Reuters (March 26, 2012); Lucas Mearian, "SEC Probes High-Speed Traders," Compterworld (March 26, 2012); Chlistalla (2011). Commentators indicated recently that "[1]eading fund managers are calling for greater regulation of high frequency trading which they warn is resulting in market manipulation"; see Financial Review, August 15 2102, http://afr.com/p/business/companies/crack_down on high_frequency trading_CSA9PgK9WGQJp9sgngTF7K.

FINRA even asked high frequency trading firms to disclose computer codes in order to check for manipulative strategies; see http://www.reuters.com/article/2011/09/01/us-financial-regulation-algos-idUSTRE7806J420110901
} 
In this paper, we directly examine the link between HFT and one very important and specific form of manipulation: end-of-day price dislocation. 'Closing' or 'end-of-day' [hereafter EOD] prices are extremely important for a number of reasons, including the fact that they are often used to determine the expiration value of derivative instruments and directors' options, price of seasoned equity issues, evaluate broker performance, compute net asset values of mutual funds, and compute stock indices (Comerton-Forde and Putnins, 2011). ${ }^{2}$ As such, there is massive incentive to manipulate closing price by ramping up end of day trading to push the closing price to an artificial level.

Specifically, we examine closing price manipulation from 22 stock exchanges around the world from January 2003 - June 2011. We construct a monthly panel dataset of the frequency and severity of EOD manipulation cases. Suspected cases on EOD manipulation are based on consideration of a significant increase in the EOD returns, trading activity in the last part of the day, and bid-ask spreads, as well as a reversion to natural price level the following morning (Cahart et al., 2002; Hillion and Suominen, 2004; Comerton-Forde and Putnins, 2011). These cases considered herein were in fact developed with market surveillance authorities and their software developers for the respective countries, including Capital Markets CRC, and SMARTS, Inc.

We relate the frequency and severity of EOD manipulation across markets and over time to the introduction of high-frequency trading. The actual start date of HFT, if at all, is not known with precise accuracy across all markets around the world. Nevertheless, HFT is usually

\footnotetext{
${ }^{2}$ For related work on market manipulation and exchange governance, see Aggarwal and Wu (2006), Carhart et al. (2002), Merrick et al. (2005), O'Hara (2001), O’Hara and Mendiola (2003), Peng and Röell (2009), Pirrong (1999, 2004), Röell (1993),
} 
characterized by large number of orders with smaller order quantities and tending to have short position-holding periods with almost no overnight position (Aldridge, 2009; Henrikson, 2011; Brogaard, 2010). To this end, we examine when there were unusual changes in market trading patterns over the January 2003 - June 2011 to identify when, if at all, HFT was likely having a significant influence in the marketplace. Moreover, we consider other factors such as whether or not the exchange has direct market access (DMA), which is a requirement for HFT. We examine the robustness of our findings to different proxies to identify the material presence of HFT in a marketplace.

The data examined in this paper show that marketplaces with a significant presence of HFT are substantially less likely to experience EOD manipulation and more severe EOD manipulation. In particular, the number of suspected EOD price manipulation cases decrease by 25.82 cases per month due to HFT in the most conservative estimate; given the average number of cases per month in the data is 36.56 , this means that HFT decreases the probability of EOD manipulation by $70.6 \%$. This effect is statistically significant regardless of the empirical methods and control variables. Moreover, HFT is associated with a decrease in the total trading value surrounding per suspected dislocating the EOD price case by the most conservative estimate of $42.9 \%$ relative to the average size of the total trading value surrounding per suspected dislocating the EOD price case; the least conservative estimate is $58.4 \%$. We show our findings are robust to different measures of end-of-day manipulation, including but not limited to option expiry dates, among other things.

It is noteworthy that policy mechanisms, including trading rules, surveillance and enforcement, appear to have had less of an effect in mitigating EOD manipulation. This is surprising, since these mechanisms have been shown to improve market quality in terms of 
increased liquidity, lower bid-ask spreads, improved market capitalization and greater numbers IPOs (Aitken and Siow, 2003; La Porta et al., 2006; Cumming and Johan, 2008; Jackson and Roe, 2009; Cumming et al., 2011). By contrast, HFT is prevalent only on the most liquid exchanges around the world, and yet policy mechanisms have had less of an effect in curtailing the positive outcomes of HFT in terms of less pronounced and less frequent EOD manipulation.

Our paper is related to a small but growing literature on HFT. The benefits and costs of HFT are nicely summarized by Biais and Woolley (2011). Potential benefits of HFT include: (1) HFT can help ensure that related assets remain consistently priced due to increased liquidity (Chaboud et al, 2009); (2) HFT algorithms can help traders cope with market fragmentation by fostering competition between trading mechanisms, including exchanges and other platforms; and (3) HFT algorithms can mitigate traders' cognition limits and traders' limited rationality. Brogaard (2010) found that the participation rate of HFT in the sample NASDAQ equity trading data used in his study is approximately $77 \%$ and he concluded that HFT play a vital role in the price efficiency and price discovery process. Hendershott and Riordan (2010) and Hendershott et al. (2011) find consistent evidence from NASDAQ on the important role of HFT in price discovery and liquidity.

Biasis and Woolley (2011) also note that potential costs of HFT include: (1) manipulation in various ways that are described in section 2 below; (2) adverse selection in the sense that nonHFT trades are slower and less well informed that HFT trades, thereby leading to a reduced market participation among non non-HFT traders (i.e., HFT trades impose a negative externality of adverse selection on non-HFT traders); (3) imperfect competition among HFT traders and non-HFT traders due to the large fixed costs of establishing HFTs; and (4) systematic risk, which might increase if HFT algorithms rely on similar strategies which are correlated. In respect of 
the first point, we are not aware of any systematic evidence on the effect of HFT on market manipulation. In respect of the latter point, there is mixed evidence on the impact of HFT on volatility depending on the context. Focused on the recent Flash Crash in the United States financial market that occurred on May $6^{\text {th }}, 2010$, Kirilenko, et al. (2011) argue that Highfrequency traders (HFTrs) did not activate the Flash Crash but rather intensified the market volatility. However, Brogaard (2010) finds that, rather than increasing stock volatility due to more frequent trading, HFT reduces stock volatility.

Our paper does not weight-in on each of these specific benefits or costs, but rather focuses on the narrow question of whether or not HFT affects the frequency and magnitude of EOD price dislocation. Overall, our findings imply HFT makes it more difficult for market manipulators to manipulate EOD closing prices. Our central finding is therefore consistent with the extant evidence and results in Brogaard (2010), Hendershott and Riordan (2010) and Hendershott et al. (2011) on the valuable role for HFT in facilitating price discovery. Our findings do not imply that HFT makes it more or less difficult to manipulate prices or volume in other ways, as those issues are beyond the scope of our paper. It may well be the case that future efforts in monitoring HFT are warranted among policymakers and surveillance authorities, but such efforts should not inhibit the role of HFT in facilitating a reduction in EOD manipulation.

This paper is organized as follows. Section 2 discusses EOD manipulation in relation to HFT as well as various policy mechanisms designed to curb manipulation. Section 3 describes end of day trading manipulation and high frequency trading. The data are introduced in Section 4. Section 5 presents multivariate analyses of the relation between the end of day manipulation and high frequency trading. Concluding remarks follow in the last section. 


\section{Market Manipulation}

\subsection{HFT and Market Manipulation}

There are theoretical reasons either way in terms of whether or not HFT mitigates market manipulation or exacerbates market manipulation. In this subsection, we first describe the possibility of HFT exacerbating manipulation, and then consider with some arguments as to why HFT might mitigate manipulation.

HFT, by virtue of the speed of the entering orders and execution of transactions, have the potential scope for facilitating manipulation more easily in a number of ways. First, HFT can be used to enter purchase orders at successively higher prices to create the appearance of active interest in a security, which is also termed as ramping/gouging. This type of HFT strategy is sometime referred to as 'smoking', or luring non-HFT orders (Biasis and Woolley, 2011). This can also take the form of pump and dump schemes whereby HFT is used to generate a significant increase in price and volume for a security, carry out a quick flip, and the securities are then sold (often to retail customers) at the higher price. Another similar type of price manipulation takes the form of pre-arranged trading. Pre-arranged trades involve colluding parties simultaneously entering orders at an identical price and volume, which might be easier to coordinate with across HFT systems. Because pre-arranged trades avoid the order queue, they can influence the price of a security. Similarly, market setting is a form of manipulation whereby HFT could be used to cross-orders at the short-term high or low to effect the volume weighted average price, or to set the price in one market for the purpose of a cross in another market. These forms of price manipulation are often geared towards EOD trades to manipulate the closing market price of the security, particularly since the EOD price affect the expiration value of derivative instruments 
and directors' options, the price of seasoned equity issues, broker performance evaluation, the net asset values of mutual funds, and the value of stock indices.

HFT can also be used to exacerbate spoofing. Spoofing, also known as "painting the tape", is a form of market manipulation that involves actions taken by market participants to give an improper or false impression of unusual activity or price movement in a security. Spoofing may take the form of fictitious orders, giving up priority, layering of bids-asks, and switches. The more general act of entering fictitious orders involve entering orders on one side of the market, then completing orders on the other side of the market and deleting the original order after the trade occurs. Giving up priority refers to deleting orders on one side of the market as they approach priority and then entering the order again on the same side of the market. Layering of bids-asks refers to traders or brokers that stagger orders from the same client reference at different price and volume levels to give the misleading impression of greater interest in the security from a more diverse set of exchange participants, and might be viewed as being carried out for the purpose of manipulation. Switches involve deleting orders on one side of the market as they approach priority and then entering the order again on the opposite side of the market.

Finally, the presence of HFT may manipulate markets by 'stuffing' orders, thereby making it more difficult for non-HFT orders to execute. HFT has an obvious speed advantage, and regular traders entering non-HFT orders suffer a technological disadvantage from not being able to have orders reach the exchange in the same time period. Moreover, there are large fixed costs of setting up HFT systems, and regular market participants, particularly retail participants, are less able to incur such fixed costs. 
On the other hand, there are at least two reasons to believe that HFT will on average curtail market manipulation for the following reasons. First, exchange surveillance systems are designed to pick up patterns of illegal manipulation, and not one-off manipulation. HFT orders are by definition following a computer algorithm, and therefore HFT systems set with the view towards manipulation are much more likely to set off a real-time alert to a securities surveillance officer (Cumming and Johan, 2008). Second, HFT has been reported to have significance benefits of increasing liquidity, reducing bid-ask spreads and facilitating price discovery (Brogaard, 2010; Hendershott and Riordan, 2010; Hendershott et al., 2011; for related work see also Bajgrowicz and Scaillet, 2012; Edelen and Kadlec, 2012). It is much more difficult for manipulators to engage in market manipulation in the presence of greater market efficiency (Aitken and Siow (2003).

Overall, given the theoretical reasons either way in terms of whether HFT mitigates or exacerbates manipulation, it is necessary to test the effect with the use of large sample data from many exchanges around the world. For the first time, we provide such tests in the empirical analyses in the subsequent sections of this paper.

\subsection{Trading Rules, Surveillance and Other Factors Pertinent to Manipulation}

Apart from HFT, there are a number of factors that can affect the likelihood of manipulation across exchanges and over time. First, surveillance systems are not of equal quality across countries, and superior systems are more likely to curtail the presence of manipulators (Cumming and Johan, 2008). Second, exchange trading rules have the ability to improve market liquidity (Cumming et al., 2011) and have the ability to signal to market 
participants that specific types of illegal activity are illegal. Third, the quality of enforcement of illegal activity varies across countries (La Porta et al., 1998, 2006 ; Jackson and Roe, 2009), which in turn can influence the likelihood that manipulators will be present in a marketplace.

In addition to rules, surveillance and enforcement, there are other market wide differences across countries and exchanges. In particular, some exchanges are much more liquid for reasons related to the development of the particular exchange or national economy. To this end, when assessing the presence of market manipulation, it is important to account for market condition differences across exchanges as well as over time. We consider these factors in our empirical tests below.

\section{Data}

Our sample comprises 22 stock exchanges whose trading data are included in commonly used data sources such as Thomson Reuters Datastream. The sample comprises Australia, Canada, China (Shanghai and Shenzhen), Germany, Hong Kong, India (Bombay and the National Stock Exchange of India), Japan, Malaysia, New Zealand, Norway, Singapore, South Korea, Sweden, Switzerland, Taiwan, the U.K., and the U.S. (NASDAQ and NYSE). The start date of HFT in the sample was determined with the methods described in the Appendix of this paper.

International start dates of algorithmic trading (AT) and HFT are not well delineated or even known by most exchanges themselves (Aitken et al., 2012). One approach is to identify news announcements on the timing of co-location (Boehmer et al., 2012). Co-location involves 
an exchange renting a space to the trading firm next to the trading facility, which provides added speed for the flow of time-sensitive information. When one asks the directors of the exchange themselves, it becomes quite clear that the precise start date is not always known due to the differential timing and ambiguous presence of AT and HFT orders in the market. AT and HFT orders in all most countries began years in advance of co-location (this fact is documented in Aitken et al., 2012). High frequency traders themselves are widely known to have physically located themselves next to the exchange in order to obtain time advantages, and established such proximate location long before co-location started. Co-location is not a pre-requisite for algorithmic or high-frequency trading. Therefore, even with proxies for co-location start dates, where defined, such start dates do not measure "effective" dates. "Effective" refers to the impact on the marketplace. Impact in this case is most commonly studied by exchange participants through unusual and permanent drops in trading size. Therefore, as explained further in the Appendix, we focus on the effective date and not the co-location date. In our multivariate empirical tests below, we nevertheless include the co-location date as well as the effective HFT date in case there is an added marginal effect of co-location services offered by the exchange.

The definitions and source of the variables used in the analyses are provided in Table 1. Our main dependent variables are the number of suspected dislocating the EOD price cases and the average trading value surrounding per suspected dislocating the EOD price case. The dependent variables are based on actual identified suspected cases from surveillance authorities via SMARTS Group, Inc., and CMCRC. SMARTS provides surveillance software to over 40 exchanges around the world. The SMARTS surveillance staff constructed the dislocation of 
EOD price case by looking at the price change between the last trade price $\left(\mathrm{P}_{\mathrm{t}}\right)^{3}$ and last available trade price 15 minutes before the continuous trading period ends $\left(\mathrm{P}_{\mathrm{t}-15)}\right.$. A price movement is abnormal if it is four standard deviations away from the mean abnormal price change during the past 100 trading days benchmarking period. To be considered as dislocation of EOD price case, the price movement between the last trade price $\left(\mathrm{P}_{t}\right)$ and the next day opening price $\left(\mathrm{P}_{t+1}\right)$, and between last trade price $\left(\mathrm{P}_{\mathrm{t}}\right)$ and last available trade price 15 minutes before the continuous trading period ends $\left(\mathrm{P}_{\mathrm{t}-15}\right)$ has to be equal or bigger than $50 \%{ }^{4}$ Table 2 indicates that the average (median) number of suspected dislocating the EOD price cases 35.78 (14) per exchange month in the sample, with a range from minimum zero to maximum of 1645. The average (median) total trading value surrounding per suspected dislocating the EOD price case is US\$670,971.8(\$136,814.2).

[Tables 1 and 2 About Here]

We use several exchange level variables covering monthly observations from January 2003 to June 2011, the period considered by this study. The domestic market capitalization at the end of each month, monthly total trading volume, and data for the total number of trades for each stock exchange are obtained from Capital Markets Cooperative Research Centre (CMCRC). Some observations are missing, such as index values from La Porta et al. (1998) and Jackson and Roe (2009). . Similarly, we filled in missing values for the indices based on taking the median and mean values of the indices for the missing countries based on the countries of the same legal origin. Again, the results were not materially different. We discuss these different sets of results explicitly below.

\footnotetext{
${ }^{3}$ For securities exchanges that have closing auction, the close price at auction is used $\left(\mathrm{P}_{\text {auction }}\right)$.

${ }^{4}\left(\mathrm{P}_{\text {auction or }} \mathrm{P}_{\mathrm{t}-} \mathrm{P}_{\mathrm{t}+1}\right) /\left(\mathrm{P}_{\text {auction or }} \mathrm{P}_{\mathrm{t}}-\mathrm{P}_{\mathrm{t}-15}\right) \geq 50 \%$
} 
Surveillance data are used from Cumming and Johan (2008) and updated to 2011. Cumming and Johan surveyed 25 exchanges around the world to ascertain the extent of singleand cross-market surveillance. The data were obtained confidentially because a would-be manipulator might trade in ways that could not be detected if precise information about surveillance activity was available. The data are based on an equally weighted index that adds one every time a different type of single- and cross-market manipulation is monitored.

Exchange trading rule indices are obtained from Cumming et al. (2011), as summarized in Table 3. Trading rules for these stock exchanges are found on the each exchange's webpage, with the sole exception of China, where the pertinent trading rules for the Shanghai and Shenzhen exchange are found on the China Securities and Regulatory Commission webpage. There are three primary legal indices introduced: the Insider Trading Rules Index, the Market Manipulation Rules Index, and the Broker-Agency Conflict Rules Index. The Market Manipulation Rules Index consists of four subcomponents: the Price Manipulation Rules Index, the Volume Manipulation Rules Index, the Spoofing Manipulation Rules Index, and the False Disclosure Rules Index. These indices are summarized in Table 2 for the pre- and post-MiFID periods for January 2003- June 2011. The indices are created by summing up the number of specific provisions in the exchange trading rules in each country. In the post-MiFID period the Insider Trading Rules Index varies from a low value of zero (for a number of exchanges listed in Table 2) to ten (for NASDAQ). The Market Manipulation Rules Index varies from a low value of two (for Malaysia, Taiwan and Tokyo) to 13 (for London, NYSE). The Broker-Agency Conflict Rules Index varies from a low value of zero (for Australia, Hong Kong, Germany, Shanghai, Shenzhen, Taiwan, Tokyo and OSLO) to five (for NASDAQ). The total trading rule index is the sum of the Insider Trading Rules Index, the Market Manipulation Index, and the 
Broker-Agency Conflict Rules Index. While present results in our regressions with the use of the Total Rules Index, the use of sub-indices does not materially impact our conclusions and findings herein.

\section{[Insert Table 3 About Here]}

We also acquire a series of law and finance indices from La Porta et al. $(1998,2006)$ and Spamann (2010), which includes the rule of law and efficiency of the judiciary. Other legal indices were considered, but they did not impact the empirical tests reported below and are therefore excluded for conciseness. Although we do have information on surveillance mentioned immediately above, we do not have data on enforcement of the trading rules that we analyze in this article; nevertheless, our understanding from our data sources for surveillance in Cumming and Johan (2008) is that enforcement is highly correlated with surveillance because otherwise exchanges would not bother to carry out surveillance. To further proxy enforcement, we use prior indices of enforcement such as efficiency of the judiciary. In other work, note that La Porta et al. (2006) finds evidence that private enforcement facilitates the development of stock markets, while Jackson and Roe (2009) find stronger evidence on the value of liability standards and public enforcement. The difference in Jackson and Roe is that they employ more detailed resource-based measures such as budgets/GDP and staffing/population to study enforcement. These enforcement measures differ significantly across countries, but not over time. We have considered all of the indices in the La Porta et al. (2006) and Jackson and Roe (2009); inclusion/exclusion of these indices does not materially affect the conclusions regarding HFT and other things presented herein. 
To control for the influence of market specific changes, we include control variables for volatility. Also, we include both exchange and year-dummy variables in our multivariate analyses in section 4 below.

\section{Univariate Tests}

Table 4 provides a comparison of means and medians tests for the number of suspected dislocating the EOD price cases in Panel A, and the total trading value surrounding per suspected dislocating the EOD price case in Panel B.

\section{[Insert Table 4 About Here]}

Table 4 Panel A shows that the market-capitalization weighted median number of suspected dislocating the EOD price cases is 0.01in HFT exchange time periods, which is lower than the 0.13 weighted median number of cases in non HFT-exchange time periods; however, due to a few outliers, the market-capitalization weighted average for the number of EOD cases is higher at 3.54 for HFT than the 0.64 for non-HFT countries. These differences in means and medians are significant at the $1 \%$. Moreover, considering the impact of introducing HFT in a market, Table 4 Panel A shows that post-HFT exchanges had on average (median) 1.05 (0.004) cases, which is lower than the average (median) of $6.70(0.04)$ in pre-HFT time periods. Again, these differences in means and medians are significant at the $1 \%$ level.

Figure 1 plots the indexed average number of EOD manipulation cases for HFT and nonHFT exchanges. The values for HFT countries are presented surrounding the date 0 , which is indexed to the start time of HFT in a particular country to compare pre- and post-HFT in a given 
country. Figure 1 is consistent with the tests in Table 4 Panel A highlighting the fact that EOD manipulation cases are less frequently associated with HFT both in terms of comparing pre- and post-HFT time periods and HFT and non-HFT exchanges.

\section{[Insert Figure 1 About Here]}

Table 4 Panel B shows that the market-capitalization weighted average (median) trading value surrounding suspected discloating the EOD price cases is 40686.67 (27.82) in HFT exchange time periods, which is lower than the 118325.60 (269.01) average (median) trading value surrounding cases in non HFT-exchange time periods. These differences are significant at the $1 \%$ level. We also compare the values pre- and post-introduction of HFT. Considering the impact of introducing HFT in a market, Table 4 Panel B shows that post-HFT exchanges had a market capitalization weighted average (median) 22465.07 (35.45) trading value surrounding cases, which is lower (higher) than the average (median) of 63554.75 (18.75) in pre-HFT time periods. This difference in means is significant at the $1 \%$ level, but the difference in median is not statistically significant.

Figure 2 plots the indexed total trading value surrounding EOD manipulation cases for HFT and non-HFT exchanges. The values for HFT countries are presented surrounding the date 0 , which is indexed to the start time of HFT in a particular country to compare pre- and postHFT in a given country. Moreover, the indexing of the values negates the scale effect in Table 4 Panel B for comparing HFT and non-HFT countries discussed above. Figure 2 clearly shows that EOD manipulation cases are less frequently associated with HFT both in terms of comparing pre- and post-HFT time periods and HFT and non-HFT exchanges.

[Insert Figure 2 About Here] 
Overall, these comparison tests support the view that HFT is associated with a lower frequency of EOD manipulation. Further, the pre- versus post-HFT tests support the view that there is less trading value surrounding EOD manipulation cases. The HFT versus non-HFT value tests highlight the need to control for other things being equal across exchanges, as done in the next section with the multivariate tests.

Table 5 presents a correlation matrix for the main variables used in the multivariate tests provided in the next section. The correlations highlight similar trends as in the comparison tests. As well, the correlations show areas in which collinearity is potentially problematic for regression analyses, and as such we present alternative specifications with and without collinear variables in the regressions in the subsequent section.

[Insert Table 5 About Here]

\section{Multivariate Tests}

\subsection{Primary Results}

Table 6 presents panel data regression results with 8 alternative econometric models for the two dependent variables for the number of EOD manipulation cases and the average trading value surrounding such cases. The eight models include different sets of explanatory variables to highlight robustness. Model 1 present the results with HFT dummy alone and Model 2 presents the results with both HFT and Co-Location dummy. Models 3-8 include the HFT variable along with microstructure control variables in terms of exchange characteristics such as market capitalization, dollar volume, and the number of trades. Models 5-8 include different sets of 
trading rule and enforcement variables, which is useful to show explicitly since many of these variables are highly correlated. Models 6 and 8 include a complete set of variables all at once. Models 7 and 8 exclude the US observations. We do not use two-way clustering in some of the models due to estimation problems with the time-invariant legal/country variables. Models 1, 2, and 5-8 use one-way clustering of errors by year, while Models 3 and 4 use two-way clustering by month and exchange.

\section{[Insert Table 6 About Here]}

Table 6 Panel A presents the regression results for the number of suspected EOD price cases. The data show HFT is negatively associated with the number of suspected EOD cases, and in each model the effect is significant at the $1 \%$ level of significance. In terms of the economic significance, the data indicate that HFT gives rise to an average of 25.82 fewer cases in the most conservative estimate in Model 4, and up to a reduction in cases by 40.84 . Given that the average number of cases per month per exchange is 36.56 , this is equivalent to a conservative estimate of a reduction by $70.6 \%$ in the number of cases with HFT. $^{5}$

The co-location variable is significant at the 5\% level in Model 2 of Table 6 Panel A, showing an added reduction in the number of cases by 7.8. However, this effect is statistically insignificant in all of the other models in Table 6 Panel A. This finding is consistent with the

\footnotetext{
${ }^{5}$ Also, we considered a difference-in-differences estimator using the average start date for HFT across exchanges. We do not explicitly report this estimator because the average start date is an imperfect choice since the start dates vary widely across exchanges (see the Appendix). This estimator showed a reduction in the number of cases by 16.56 (significant at the $1 \%$ level), which is a reduction by $45.2 \%$ relative to the average number of cases of 36.56 . Likewise, we considered other specifications all of which yielded consistent results that the number of cases goes down.
} 
fact that HFT started long in advance of co-location (see the Appendix; see also Aitken et al., 2012).

The control variables in Table 6 Panel A show some consistent statistical significance in ways that are expected. EOD manipulation is less common with public enforcement (Models 5, 7 and 9), less common among higher rule of law countries (Models 4-8), and more common when volatility is higher (Models 3-8). These effects are significant at the $1 \%$ level. The other controls are either insignificant or not robust across different specifications.

Table 6 Panel B presents the regression results for the number of suspected EOD price cases. The data indicate that HFT has a very pronounced role in mitigating the trading value surrounding EOD dislocating cases, and this effect is statistically significant at the $10 \%$ level in Models 1, 2 and 7, at the 5\% level in Models 3, 5, and the 1\% level in Model 4 and 6 . The economic significance shows that HFT curtails extreme events with EOD manipulation cases. The most conservative estimate is from Model 2 in Panel B, which shows a reduction by 294162.7. Given the average trading value surrounding EOD cases is 685637.8 , this reduction is economically significant at $42.9 \%$ of the average value. The least conservative estimate is from Model 6 in Panel B which shows a reduction by 400167.5 , or $58.4 \%$.

The co-location variable in Table 6 Panel B is insignificant in all specifications. Hence, that latter timing of co-location relative to the start of HFT (Appendix; see also Aitken et al., 2012) has on average had no material effect on trading values surrounding suspected cases.

The control variables show some consistent significance. Trading value surrounding suspected cases is higher with public enforcement (Models 5-8) and lower with average market trade size (Models 3-8). Log of volume is significant in Models 3 and 4, but not robust in the 
other models. Similarly some of the surveillance and enforcement estimates are significant but the effects are not robust.

\subsection{Robustness Checks}

In the course of our empirical analyses we carried out a number of robustness checks. First, we considered different specifications of the dependent variables, such as without winsorizing and winsorizing at different levels, different time periods, etc. Results with winsozing at the $99^{\text {th }}$ percentile appear in Table 7 . The findings are very consistent with that reported in Table 6, with the exception that the economic significance or the size of the effects is slightly smaller as expected.

\section{[Insert Table 7 About Here]}

Second, we report findings with other measures of end-of-day manipulation by examining only end-of-month cases and only cases of end-of-day manipulation that match with option expiry dates. Those findings are reports in Table 8. The results are consistent with those reported for the dependent variables in the other tables with all possible end-of-day manipulation cases.

\section{[Insert Table 8 About Here]}

Third, instead of using total trading rules, we used subsets of the trading rules indices. Fourth, we considered other measures of law quality such as antidirector rights (La Porta et al., 1998; Spamann, 2010), disclosure (La Porta et al., 2006) and other proxies for the resources devoted to securities regulation (Jackson and Roe, 2009). Fifth, we considered other instrumental variable and difference-in-differences specifications (see footnote 5), such as with 
lagged dependent variables and other specifications. Sixth, we considered possible outlier time periods and outlier exchanges. Seventh, we considered other proxies for HFT, such as trending variables instead of a binary variable, to account for increases in HFT over time. Eighth, we have considered other explanatory variables, including but not limited to other measures of volatility other than that reported in the tables. These alternative models and checks, among others, did not suggest material differences to the array of results reported in the tables. Alternative specifications are available on request.

Finally, recall in section 3 above we noted that some observations are missing, such as data from and index values from La Porta et al. (1998) and Jackson and Roe (2009). We assessed robustness to excluding these legal observations by filling in missing values for the indices based on taking the median and mean values of the indices for the missing countries based on the countries of the same legal origin. . The results are extremely similar for each of Panels A and B in Table 6 when we re-run the regressions with the full sample. We note that Model 1 in Table 6 uses the full set of observations and the findings are very consistent with the regressions which include variables with some missing observations. Again, additional specifications and full details are available on request.

\section{Conclusions}

This paper examined the relationship between HFT and EOD manipulation in 22 exchanges around the world spanning the period January 2003 - June 2011. EOD manipulation is one of the most common and important forms of manipulation in view of the many important functions of EOD prices, such as computing index values, prices for related securities, 
compensation, and computing fund net asset values. We examined data used by actual surveillance systems to ascertain suspected EOD manipulation cases in a way that is consistent across exchanges. We related the frequency and trading value surrounding suspected EOD manipulation cases. We controlled for a variety of market conditions, legal conditions, trading rules, surveillance and other differences across exchanges.

The data examined unambiguously indicate that in the presence of HFT, EOD manipulation are on average less frequent in terms of the number of EOD manipulation cases in the presence, and on less pronounced in terms of the average EOD trading value surrounding suspected cases. In fact, HFT is the most robust and statistically significant factor that affects EOD manipulation.

The data also indicate that EOD manipulation varies frequently with market conditions. As well, the data indicate somewhat related to surveillance and regulatory standards in a country. But the importance of HFT is much more consistently pronounced and effective in terms of mitigating the frequency and magnitude of manipulation.

Overall, the data support the view that the price discovery and liquidity function of HFT on average significantly dominates and role that HFT may play facilitating market manipulation, at least with respect to the very important EOD manipulation. Future research could explore the effect of HFT on other types of manipulation. As well, future research could explore differences in manipulation across different HFT firms pursuing different strategies. It is possible that there are some HFT manipulators present in the market, and if so, it would be important to know the context in which their trades are executed to enable surveillance authorities and regulators to detect such forms of manipulation. But overall the data considered herein show that the presence 
of HFT has done more good than harm and that manipulation, at least EOD manipulation, is not as pronounced under HFT as current regulatory concerns might suggest.

\section{References}

Aitken, M., Cumming, D.J. and Zhan, F. (2012). "Identifying international start dates for algorithmic trading and high frequency trading." Available at SSRN: http://ssrn.com/abstract $=2172455$

Aitken, M., Siow, A., (2003). "Ranking equity markets on the basis of market efficiency and integrity." In: H. Skeete, Hewlett-Packard Handbook of World Stock, Derivative \& Commodity Exchanges 2003. Dublin, pp. xliv-lv.

Aggarwal, R.K., Wu, G. (2006). "Stock market manipulations.” Journal of Business 79, 19151953.

Aldridge, I. (2009). High Frequency Trading: A Practical Guide to Algorithmic Strategies and Trading Systems. Wiley Trading, John Wiley \& Sons.

Bajgrowicz, P., and O. Scaillet. (2012). "Technical Trading Revisited: False Discoveries, Persistence Tests, and Transaction Costs," Journal of Financial Economics, forthcoming

Biasis, B., and P. Woolley (2011). "High Frequency Trading." Working Paper, Toulouse School of Economics and London School of Economics.

Boehmer, E., Fong, K. Y. L., and Wu, J. (2012) “Algorithmic Trading and Changes in Firms' Equity Capital” Available at SSRN: http://ssrn.com/abstract=2050856

Brogaard, J. (2010). "High Frequency Trading and its Impact on Market quality." Northwestern University Kellogg School of Management. Working Paper. July, 2010.

Carhart, M., R. Kaniel, D. Musto, and A. Reed, (2002). "Leaning for the Tape: Evidence of Gaming Behavior in Equity Mutual Funds," Journal of Finance 57, 661-693.

Chaboud, A., E. Hjalmarsson, C. Vega, and B. Chiquoine (2009). "Rise of the Machines: Algorithmic Trading in the Foreign Exchange Market." Federal Reserve Board International Finance Discussion Paper No. 980.

Chlistalla, M. (2011). "High-frequency trading: better than its reputation?" In FOCUS. Retrieved from http://www.world-exchanges.org/focus/2011-09/m-2-2.php

Comerton-Forde, C., and T.J. Putnins (2011) "Measuring Closing Price Manipulation.” Journal of Financial Intermediation, vol.20:2, pp. 135-58 
Comerton-Forde, C, and J. Rydge, (2006). "Market Integrity and Surveillance Effort," Journal of Financial Services Research 29, 149-172.

Cumming, D., and S.A. Johan, (2008). "Global Market Surveillance." American Law and Economics Review, 10, 454-506.

Cumming, D.J., S.A. Johan, D. Li (2011). "Exchange Trading Rules and Stock Market Liquidity," Journal of Financial Economics 99(3), 651-671.

Easley, D., M.M. Lopez de Prado, and M. O'Hara, 2011. "The Microstructure of the 'Flash Crash': Flow Toxicity, Liquidity Crashes and the Probability of Informed Trading," The Journal of Portfolio Management, 37, 118-128.

Edelen, R. M., G. B. Kadlec. (2012). "Delegated Trading and the Speed of Adjustment in Security Prices.” Journal of Financial Economics, 103(2), 294-307.

Grant, J. (2011, April 12th). "High-frequency boom time hits slowdown.” Financial Times.

Hendershott, T., C.M. Jones, and A.J. Menkveld (2011). "Does Algorithmic Trading Improve Liquidity" Journal of Finance 66, 1-33.

Hendershott, T., and R. Riordan (2010). "High Frequency Trading and Price Discovery" Working Paper, University of California, Berkeley.

Henrikson, F. (2011). "Characteristics of High-Frequency Trading." Royal Institute of Technology, Sweden, Working Thesis, October, 2011.

Hillion, P., and M. Suominen (2004). "The Manipulation of Closing Prices." Journal of Financial Markets 7, 351-375.

Jackson, H.E., and M.J. Roe (2009). "Public and Private Enforcement of Securities Laws: Resource-Based Evidence,” Journal of Financial Economics 93, 207-238.

Kirilenko, A., Kyle, A., Samadi, M., and Tuzun, T. (2011). "The Flash Crash: The Impact of High Frequency Trading on an Electronic Market." Working Paper.

La Porta, R., Lopez-de-Silanes, F., Shleifer, A., Vishny, R., (1998). “Law and finance.” Journal of Political Economy 106, 1113-1155.

La Porta, R., F. Lopez-de-Silanes, A. Shleifer (2006). "What Works in Securities Laws?" Journal of Finance 61, 1-32.

Menkveld, A. (2012). “High Frequency Trading and the New-Market Makers.” Working Paper. 
Merrick, J.J. Jr., Naik, N.Y. ,Yadav P.K. (2005). "Strategic trading behavior and price distortion in a manipulated market: anatomy of a squeeze." Journal of Financial Economics 77, $171-218$.

O’Hara, M. (2001). “Overview: market structure issues in market liquidity,” in Market Liquidity: Proceedings of a Workshop Held at the BIS, BIS Papers, No. 2, April, Basel, 1-8.

O'Hara, M., Mendiola, A.M. (2003). "Taking stock in stock markets: the changing governance of exchanges." Working paper. Cornell University, NY.

O’Reilly, R. (2012). "High Frequency Trading: Are Our Vital Capital Markets at Risk from a Rampant Form of Trading that Ignored Business Fundamentals?" The Analyst (March 2012).

Peng, L., and Röell, A. (2009). "Managerial incentives and stock price manipulation," CEPR Discussion Paper No. DP7442.

Petersen, M.A. (2009). "Estimating standard errors in finance panel data sets: comparing approaches.” Review of Financial Studies 22, 435-480.

Pirrong, C. (1999). "The organization of financial exchange markets: theory and evidence," Journal of Financial Markets 2, 329-357.

Pirrong, S.C. (2004). Detecting manipulation in futures markets: the Ferruzi soybean episode. American Law and Economics Review 6, 28-71.

Röell, A. (1992). "Comparing the performance of stock exchange trading systems," In: J. Fingleton and D. Schoenmaker, (Eds.), The Internationalisation of Capital Markets and the Regulatory Response. Kluwer, Amsterdam.

Spamann, H. (2010). “The 'antidirector rights index' revisited.” Review of Financial Studies 23, 467-486.

Zhang, F, X. (2010). High-Frequency Trading, Stock Volatility, and Price Discovery. Yale University. Working Paper. 


\section{Appendix. High Frequency Trading Effective Dates}

High-frequency trading (HFT) is usually characterized by large number of orders with smaller order quantities and tending to have short position-holding periods with almost no overnight position (Aldridge, 2009; Henrikson, 2011; Brogaard, 2010).

Many studies on HFT activities use data at trades and quotes level with detailed identification code to identify HFTrs vs. non-HFTrs. Those studies often focus on single exchange or a group of highly liquid stocks over a short period (Brogaard, 2010; Kirilendo, et al., 2011; Menkveld, 2012). An optimal proxy to define the HFTr influence in our study would be a percentage of trading volume/value by HFTr over the total market trading volume/value. Our study covers twenty-two exchanges in seventeen countries over a period nine years. Obtaining detailed trade and quote data over the whole period for all exchanges in our study was nearly impossible. As such, we have developed a proxy to identify the impact of activities by HTFrs in each exchange and used this proxy to demonstrate whether or not HFT have significant impact on market quality. In other words, we are not trying to pin point the start date of HFT activities in each exchange rather we are trying to identify the period of time that HFTrs have flourished and have significant market influence.

In order to identify the start time of HFTrs' influence on a market, we first check whether the exchange in our sample offers direct market access (DMA). Eighteen out of twenty-two exchanges either have DMA access earlier compared to the start period of our data sample or have just began to offer DMA during the period of sample coverage. Second, we obtained the monthly on market trading volume and number of trade for each exchange from January 2003 to December 2011 and calculate the average monthly market trading size as the monthly total on market trading volume over the monthly total number of trades. We define the start month of HFTr influence on the market as the first of four continuously declining months in average market trading size or the biggest single drop from previous month. We also exclude significant declines during the financial crisis period between 2007 and 2008. For example, the maximum four months decline for the Australian Stock Exchange (ASE) is 42 percent which started on April, 2006 and the biggest single decline in trade size for OSLO Stock Exchange (OLSO) is 48 percent which occurred on May 2005. Therefore, we define the HFT start date for ASE and OSE as April 2006 and May 2005, respectively. We also looked at both the three-month and five-month continuous declines in average market trading size and found the results to be similar. Few exchanges have continuously declines in trading size over five months. Among eighteen exchanges, we were unable to observe any pattern of significant change for 
Singapore Stock Exchange (SGX), Hong Kong Stock Exchange (HKX), or the two Korean stock exchanges (KOE and KSC) except during financial crisis period. In these cases, we were unable to define a HFT start date. Three exchanges NASDAQ, CHI-X London (CHIX) and XETRA German (XET) have a HFT start date at the beginning of the data period.

Our final list contains fourteen exchanges from eleven different countries. We acknowledge that our definition of HFT activities may exclude HFT activities in certain exchanges. However, such bias will work against our study and make a consistent finding more difficult to obtain. Nevertheless, our findings in Table 6 show that HFT activities have a significant impact on both price dislocating cases and total trading surrounding each case. To confirm that there are changes in trading behaviours between pre-HFT and post-HFT period, we performed a comparison test on both the mean and median of average trading size. Since by our definition, exchanges such as CHIX, NASDAQ, and XET have a start date at the beginning of our study period, they are excluded from the comparison test. The results of the comparison test for all other exchanges as well as the HFT start date for each exchange are listed in Table A1, and shown graphically in Figures A1 and A2. In general, on market average trading size drops significantly after the HFT date. The average trading size dropped more than fifty percent after the HFT start date in six out of ten exchanges in the table. All comparison t-statistics are significant at the one percent level except the Bombay Stock Exchange (BSE) in India, which is significant at the five percent level. The median test tells a similar story with the sole exception of the BSE which it is not significant at any level (although our findings in the paper are invariant to different treatment of the HFT variable for BSE).

Finally, note that co-location involves an exchange renting a space to the trading firm next to the trading facility, which provides added speed for the flow of time-sensitive information. Colocation is not a pre-requisite for AT or HFT. AT and HFT orders in all most countries began years in advance of co-location. High frequency traders themselves are widely known to have physically located themselves next to the exchange in order to obtain time advantages, and established such proximate location long before co-location started.

[Insert Tables A1 and A2 and Figures A1 and A2 About Here] 


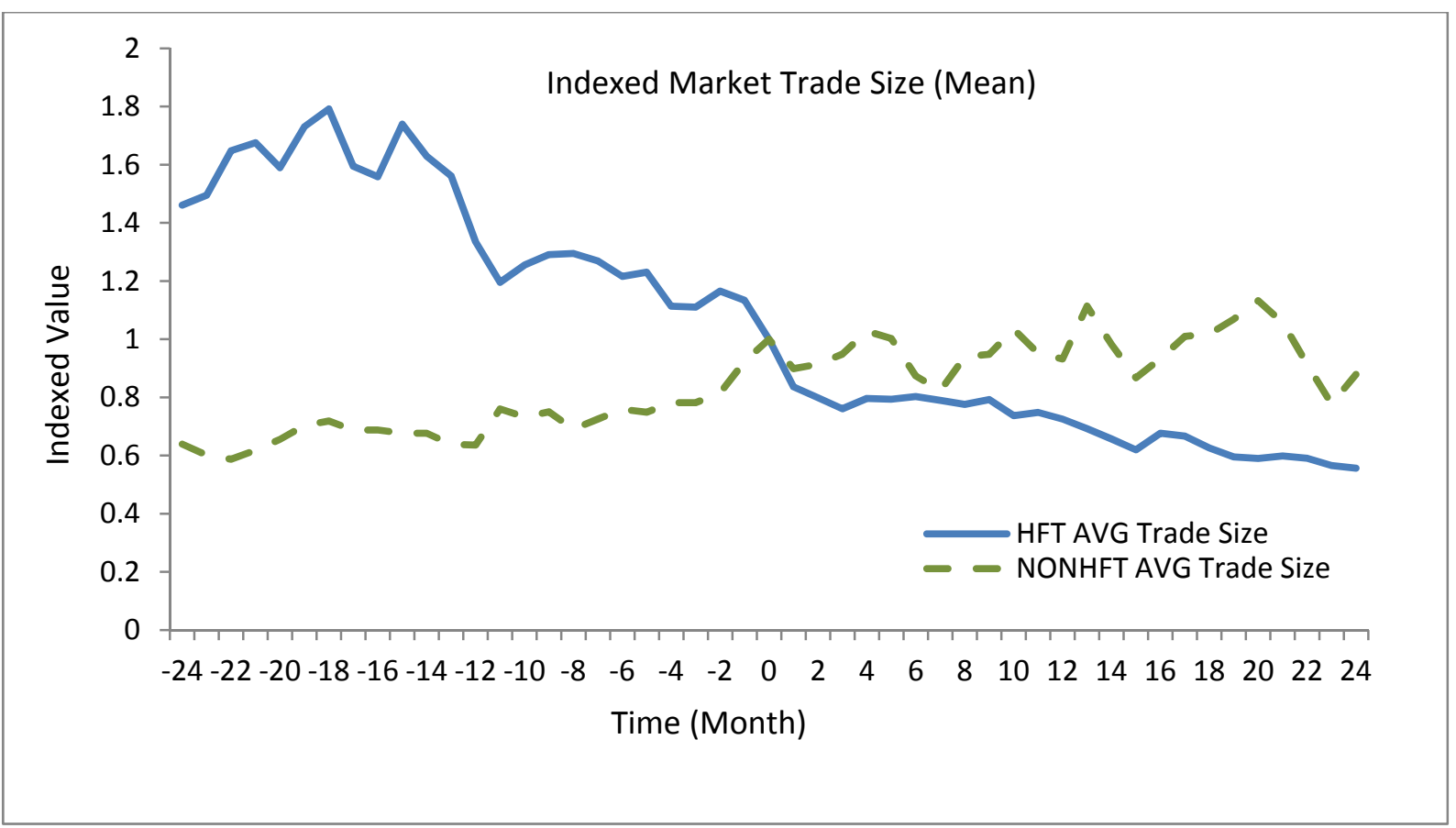

Figure A1: Plot of indexed of market average trading size. Mean of the market average trading size of HFT countries and non-HFT countries are showing here. The values for HFT countries are presented surrounding the date 0 , which is indexed to the start time of HFT in a particular country to compare pre- and post-HFT in a given country. For non-HFT countries, the zero month is January 2005 . The values for the non-HFT countries are also indexed to the zero date.

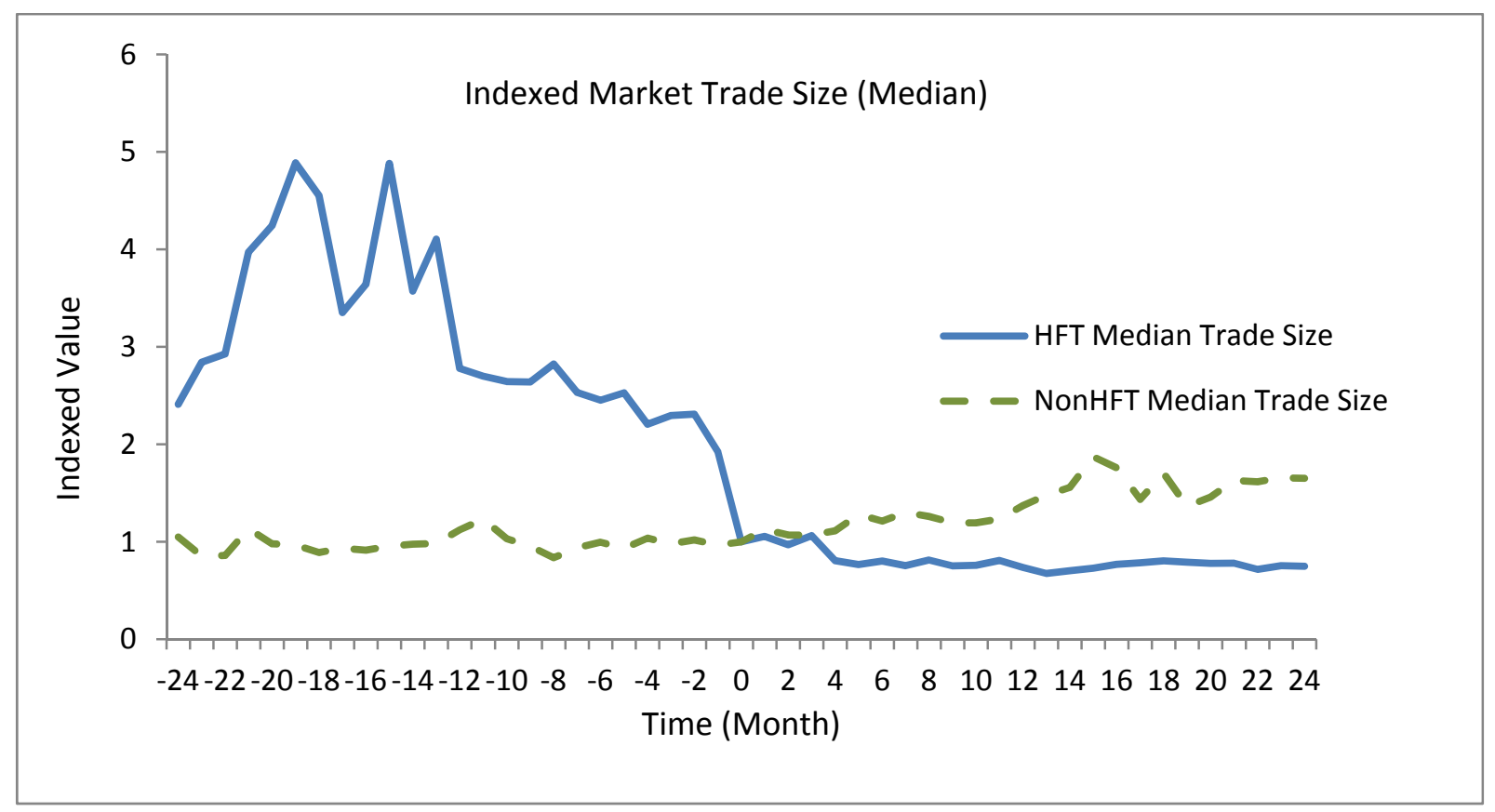

Figure A2: Plot of indexed of market average trading size. Median of the market average trading size of HFT countries and non-HFT countries are showing here. The values for HFT countries are presented surrounding the date 0 , which is indexed to the start time of HFT in a particular country to compare pre- and post-HFT in a given country. . For non-HFT countries, the zero month is January 2005. The values for the nonHFT countries are also indexed to the zero date. 
Table A1 : HFT Effective Date

This table lists the Exchange name, HFT Effective date and Comparison test on both Mean and Median of average trading size for each exchange. HFT started prior to the start date of our sample (2003/01) for CHIX, NASDAQ, and XET and hence are not listed here.

\begin{tabular}{c|c|ccc|ccc}
\hline \multirow{2}{*}{ Exchange Name } & \multirow{2}{*}{ HFT Effective Date } & \multicolumn{3}{|c|}{ Mean } & \multicolumn{2}{c}{ Median } \\
\cline { 3 - 7 } & & Pre-HFT & Post-HFT & t-statistics & Pre-HFT & Post-HFT & P-value \\
\hline OMX & $2005 / 04$ & 10333.11 & 3520.41 & $16.73^{* * *}$ & 10342.00 & 2951.00 & $\mathrm{p}<0.00^{* * *}$ \\
SWX & $2004 / 01$ & 1816.58 & 372.08 & $21.22^{* * *}$ & 1746.50 & 340.50 & $\mathrm{p}<0.00^{* * *}$ \\
TMX & $2005 / 05$ & 2618.71 & 1245.60 & $20.04^{* * *}$ & 2586.50 & 1097.00 & $\mathrm{p}<0.00^{* * *}$ \\
NSE & $2009 / 05$ & 1002.61 & 441.08 & $15.29^{* * *}$ & 988.00 & 402.50 & $\mathrm{p}<0.00^{* * *}$ \\
BSE & $2009 / 05$ & 559.21 & 428.69 & $2.34^{* *}$ & 514.50 & 376.50 & $\mathrm{p}=0.4895$ \\
TSE & $2005 / 05$ & 4409.64 & 3230.08 & $10.99^{* * *}$ & 4476.50 & 3150.00 & $\mathrm{p}<0.00^{* * *}$ \\
ASX & $2006 / 04$ & 11358.67 & 5122.21 & $15.32^{* * *}$ & 10772.00 & 4574.00 & $\mathrm{p}<0.00^{* * *}$ \\
NYSE & $2003 / 05$ & 1072.75 & 517.74 & $14.98^{* * *}$ & 1067.5 & 378.5 & $\mathrm{p}<0.00^{* * *}$ \\
LSE & $2006 / 02$ & 9793.97 & 3284.28 & $23.09^{* * *}$ & 9905.00 & 2487.00 & $\mathrm{p}<0.00^{* * *}$ \\
NZX & $2004 / 11$ & 8973.96 & 7046.03 & $4.26^{* * *}$ & 7774.50 & 6957.50 & $\mathrm{p}<0.00^{* * *}$ \\
OSLO & $2005 / 04$ & 7376.22 & 4368.37 & $6.11^{* * *}$ & 6736.00 & 3818.00 & $\mathrm{p}<0.00^{* * * *}$ \\
\hline
\end{tabular}


Table A2: Proximity Hosting/Co-Location Offer Time

\begin{tabular}{|c|c|c|}
\hline Exchange Name & $\begin{array}{l}\text { Co-Location Offer } \\
\text { Month }\end{array}$ & Note/Link \\
\hline $\begin{array}{l}\text { Stockholm Stock } \\
\text { Exchange }\end{array}$ & 2011/03 & https://www.alipesnews.com/App.aspx\#id=3474436580000000\&languageld=4000 \\
\hline Swiss Stock Exchange & 2012/04 & http://www.six-swiss-exchange.com/news/overview_en.html?id=inet_colo \\
\hline Toronto Stock Exchange & 2008/04 & Information provided by TMX Datalinx \\
\hline NASDAQ & 2007/03 & http://ir.nasdaqomx.com/common/mobile/iphone/releasedetail.cfm?releaseid=352163\&CompanyID=NDAQ\&mobileid= \\
\hline Bursa Malaysia & $2009 / 11$ & http://www.world-exchanges.org/news-views/bursa-malaysia-introduces-direct-market-access-equities-market \\
\hline NSE India & 2010/01 & http://www.nseindia.com/technology/content/tech_intro.htm \\
\hline Bombay Stock Exchange & 2010/02 & http://www.world-exchanges.org/news-views/co-location-services-bombay-stock-exchange-premises \\
\hline Tokyo Stock Exchange & 2010/01 & http://www.tse.or.jp/english/rules/co-location/index.html \\
\hline $\begin{array}{l}\text { Australia Stock } \\
\text { Exchange }\end{array}$ & 2008/Fourth Quarter & http://www.asxgroup.com.au/media/PDFs/mr030708_co-location_hosting.pdf \\
\hline XETRA Germany & 2006/08 & Information provided by XETRA Support \\
\hline NYSE & $2008 / 04$ & https://europeanequities.nyx.com/sites/europeanequities.nyx.com/files/327777.pdf \\
\hline London Stock Exchange & 2009/09 & $\begin{array}{l}\text { http://www.londonstockexchange.com/about-the-exchange/media-relations/press- } \\
\text { releases/2010//segmakescolocationdirectlyavailabletovendorsandserviceproviders.htm }\end{array}$ \\
\hline ChiX London & $2008 / 11$ & Information provided by ChiX Support \\
\hline $\begin{array}{l}\text { Hongkong Stock } \\
\text { Exchange }\end{array}$ & 2012/Fourth Quarter & http://www.hkex.com.hk/eng/newsconsul/hkexnews/2011/documents/115_e_stone\%20laying\%20fact\%20sheet.pdf \\
\hline KOSDAQ & $\mathrm{N} / \mathrm{A}$ & \\
\hline Korea Stock Exchange & N/A & \\
\hline $\begin{array}{l}\text { Singapore Stock } \\
\text { Exchange }\end{array}$ & 2011/07 & http://www.sgx.com/wps/wcm/connect/sgx_en/home/higlights/news_releases/sgx+offers+fastest+connection+to+its+markets \\
\hline $\begin{array}{l}\text { Shanghai Stock } \\
\text { Exchange }\end{array}$ & N/A & \\
\hline $\begin{array}{l}\text { Shenzhen Stock } \\
\text { Exchange }\end{array}$ & N/A & \\
\hline $\begin{array}{c}\text { Taiwan Stock Exchange } \\
\text { New Zealand Stock } \\
\text { Exchange }\end{array}$ & $\begin{array}{c}\text { 2010/Fourth Quarter } \\
\text { N/A }\end{array}$ & http://www.world-exchanges.org/news-views/taiwan-stock-exchange-launch-co-location-services \\
\hline OLSO Norway & 2010/04 & http://www.oslobors.no/ob_eng/Oslo-Boers/Trade/Delta/The-strategic-partnership-with-the-London-Stock-Exchange-Group \\
\hline
\end{tabular}




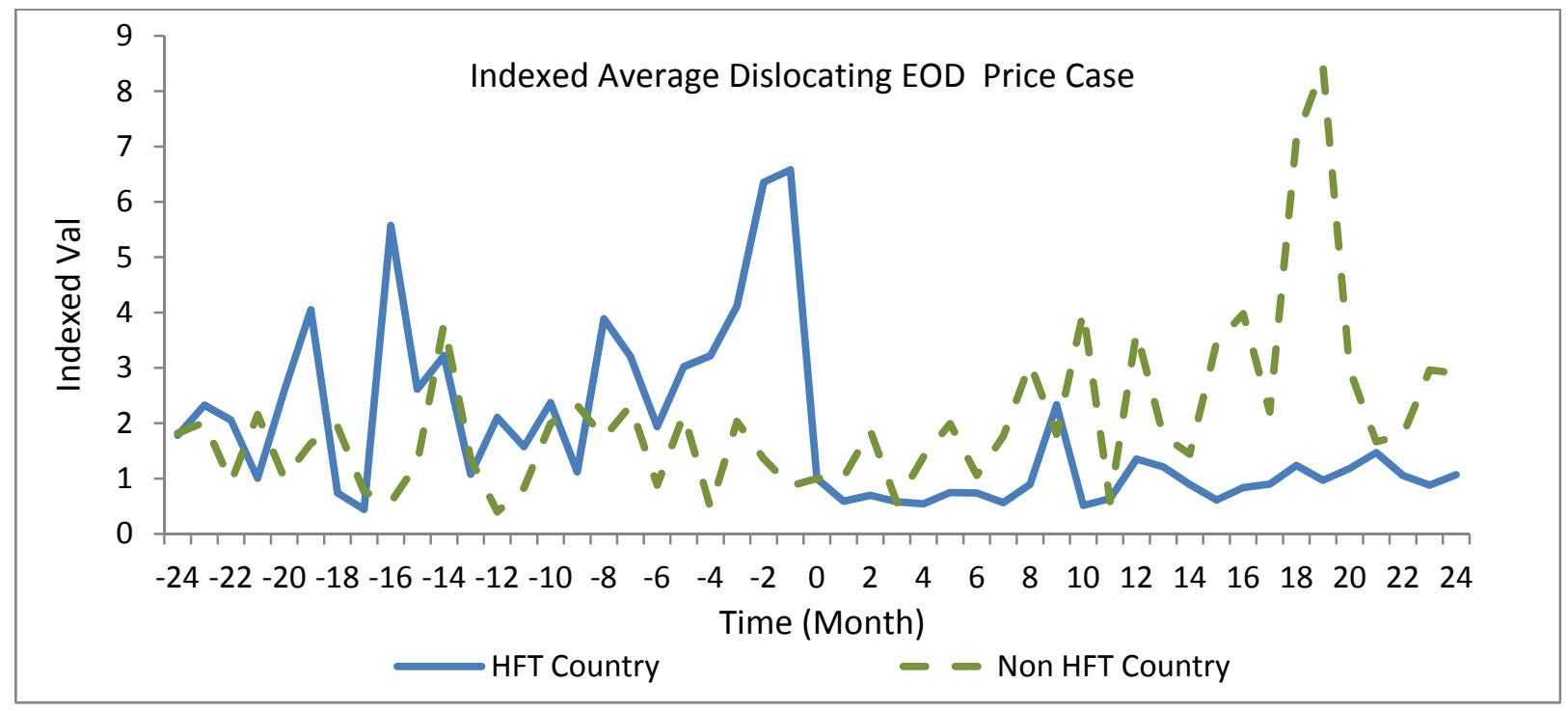

Figure 1: Plot of indexed of average (market capitalization weighted) EOD price case. Market Capitalization weighted average suspected EOD price dislocation cases of HFT countries and non-HFT countries are shown here. The values for HFT countries are presented surrounding the date 0 , which is indexed to the start time of HFT in a particular country to compare pre- and post-HFT in a given country. . For non-HFT countries, the zero month is March 2007 (Mid-point). The values for the non-HFT countries are also indexed to the zero date.

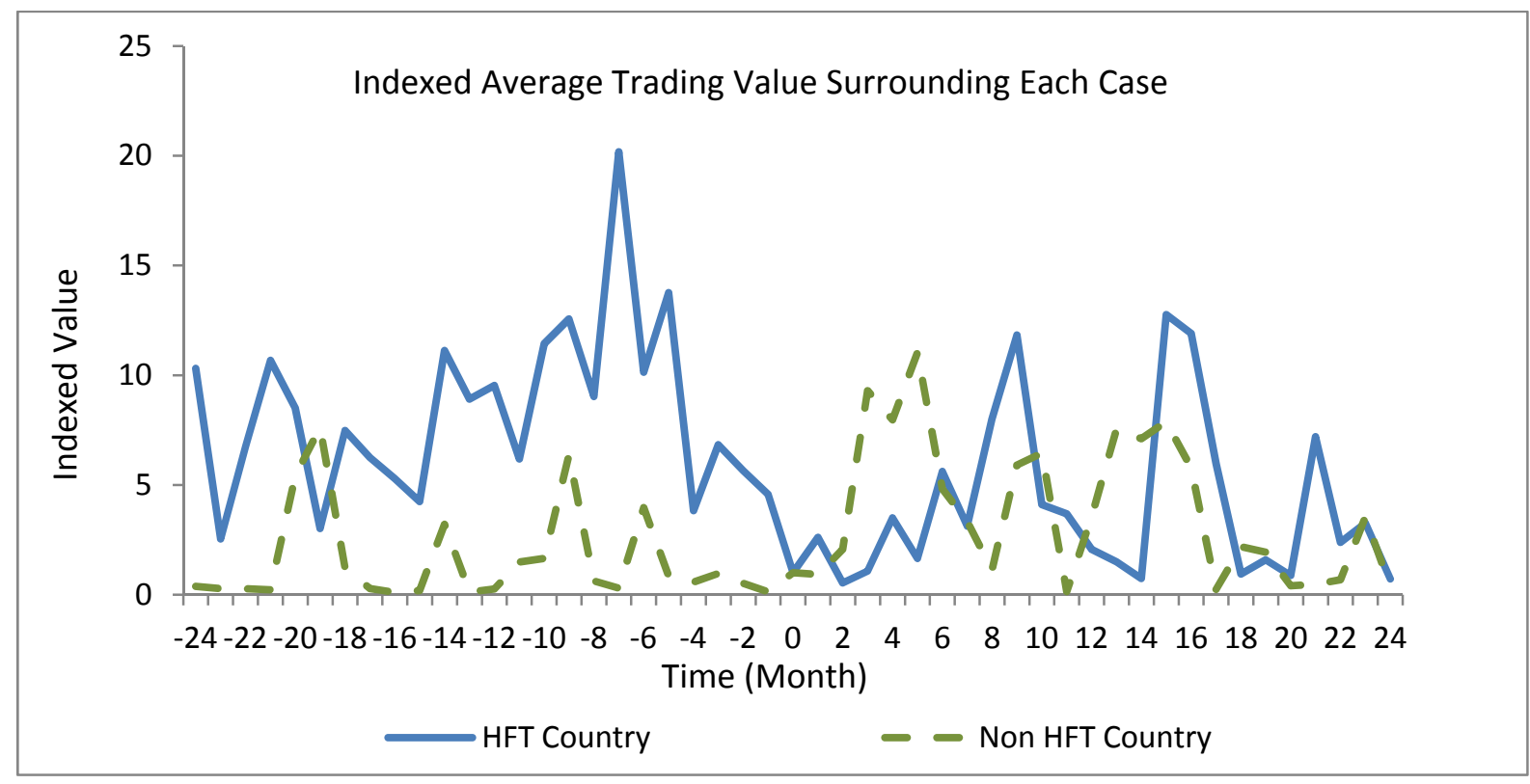

Figure 2: Plot of indexed of average (market capitalization weighted) total trading surrounding per EOD price case. Market capitalization weighted total trading value surrounding per suspected EOD dislocation case of HFT countries and non-HFT countries are shown here. The values for HFT countries are presented surrounding the date 0 , which is indexed to the start time of HFT in a particular country to compare preand post-HFT in a given country. For non-HFT countries, the zero month is March 2007 (Mid-point). The values for the non-HFT countries are also indexed to the zero date. 
Table 1.

Definition of Variables

This table defines our independent, dependent and control variables.

\begin{tabular}{c|l} 
Variable Name & Definition \\
\hline $\begin{array}{c}\text { HFT } \\
\text { Co-Location }\end{array}$ & $\begin{array}{l}\text { Dummy variable indicates when HFT starts in the market, as listed in Table A1 in the Appendix. } \\
\text { Dummy variable indicates when the exchange starts to offer the co-location services, as listed in Table A2 in the Appendix. }\end{array}$
\end{tabular}

Law/Legal Index

DLLS Public enforcement index

Public enforcement here is an index aggregating whether Public enforcement here is an index aggregating whether jail sentences for the approving body, or fine or jail sentence for the principal wrongdoer. Source: Djankov, La Porta, Lopez-de-Silanes, and Shleifer (2008a).

Efficiency of the Judiciary Index

Assessment of the "efficiency and integrity of the legal environment as it affects business, particularly foreign firms" produced by the country risk rating agency Business International Corp. It "may be taken to represent investors' assessments of conditions in the country in question." Average between 1980 and 1983. Scale from zero to 10; with lower scores, lower efficiency levels Assessment of the efficiency and integrity of the legal environment. Scale from zero to ten; with lower scores, lower efficiency levels. Source: La Porta, Lopez-de-Silanes, Shleifer, and Vishny (1998).

Assessment of the law and order tradition in the country produced by the country risk rating agency International Country Risk (ICR). Average of the months of April and October of the monthly index between 1982 and 1995. Scale from zero to 10, with

Rule of Law Indices lower scores for less tradition for law and order (we changed the scale from its original range going from zero to six). Origina data comes from International Country Risk guide. Source: La Porta, Lopez-de-Silanes, Shleifer and Vishny (1998).

Staff per million population(extrapolated sample)

Surveillance Index

Staff per million population(extrapolated sample)

Market Statistics

Log (Market Capitalization)

Log (Volume)

Log (Number of Trades)

Log (Market Volatility)

Log (GDP Per Capita)

Log (Average Market Trade Size)

$\underline{\text { Evidenced Measures of Market }}$ Quality

Suspected Dislocating the EOD Price Cases
The 2005 size of the securities regulator's staff, divided by the country's population in millions. Source: Jackson, and Roe (2009).

The principal component of (1) single market surveillance and (2) cross market surveillance. Source: Cumming and Johan (2008). Available for a subset of countries, and provided contingent on maintaining confidentiality and anonymity as exchanges do not want market participants to know all of the things they do and do not look for in their surveillance. Source: Cumming, Johan, and $\operatorname{Li}(2011)$

Sum of insider trading rules index, price manipulation rules index, volume manipulation rules index, spoofing rules index, false disclosure rules index, false disclosure rules index, market manipulation rules index, and broker-agency rules index. Source: Cumming, Johan, and $\mathrm{Li}(2011)$.

Log of domestic market capitalization in USD millions. Source: Capital Markets Cooperative Research Centre (CMCRC)

Log of total value of shares trading in USD millions. Source: Capital Markets Cooperative Research Centre (CMCRC).

Log of total number of trades in thousands in the same period. Source: Capital Markets Cooperative Research Centre (CMCRC)

Log of market volatility. Market volatility is calculated as stock market capitalization weighted volatility for each exchange. Source: Source: Capital Markets Cooperative Research Centre (CMCRC).

Log of gross domestic product (GDP) per capita in the lagged period. Source: GlobalInsight. (2003/01-2011/06)

Log of average market trade size in the same period. Source: Capital Markets Cooperative Research Centre (CMCRC).

Total number of suspected dislocating of the end of day price cases. The SMARTS surveillance staff constructed the dislocation of EOD price case by looking at the price change between the last trade price $\left(\mathrm{P}_{\mathrm{t}}\right)$ and last available trade price 15 minutes before the continuous trading period ends $\left(\mathrm{P}_{\mathrm{t}-15}\right)$. For securities exchanges that have closing auction, the close price at auction is used $\left(\mathrm{P}_{\text {auction }}\right)$. A price movement is abnormal if it is four standard deviations away from the mean abnormal price change during the past 100 trading days benchmarking period. To be considered as dislocation of EOD price case, the price movement between the last trade price $\left(\mathrm{P}_{t}\right)$ and the next day opening price $\left(\mathrm{P}_{t+1}\right)$, and between last trade price $\left(\mathrm{P}_{t}\right)$ and last available trade price 15 minutes before the continuous trading period ends $\left(\mathrm{P}_{\mathrm{t}-15}\right)$ has to be bigger than $50 \%$. $\left(\mathrm{P}_{\text {auction or }} \mathrm{P}_{\mathrm{t}-\mathrm{P}} \mathrm{P}_{\mathrm{t}+1}\right) /\left(\mathrm{P}_{\text {auction or }} \mathrm{P}_{\mathrm{t}}-\mathrm{P}_{\mathrm{t}-15}\right) \geq 50 \%$. Source: Capital Markets Cooperative Research Centre (CMCRC).

Average trading value surrounding each suspected dislocating EOD price case. Source: Capital Markets Cooperative Research Centre (CMCRC).
Surrounding Per Suspected Dislocating the EOD Price Case 
Table 2.

Trading Rule Indices

This table summarizes the index values for the trading rules for each exchange, as defined in Table 1. Panel A presents the trading rule index values for post-MiFID (Nov. 2007 - Jun. 2011; and in brackets are values for Jan. 2003 - Oct. 2007). Panel B compares the mean of trading rule index among different legal origin. The Cochran and Cox (1950) t-statistics are shown in Panel B and the *, **, $* * *$ denote significance at the $10 \%, 5 \%$, and $1 \%$ levels, respectively.

Panel A:

\begin{tabular}{|c|c|c|c|c|c|c|c|}
\hline Exchange & $\begin{array}{c}\text { Price } \\
\text { Manipulation } \\
\text { Index }\end{array}$ & $\begin{array}{c}\text { Volume } \\
\text { Manipulation } \\
\text { Index }\end{array}$ & $\begin{array}{l}\text { Spoofing } \\
\text { Index }\end{array}$ & $\begin{array}{l}\text { False } \\
\text { Disclosure } \\
\text { Index }\end{array}$ & $\begin{array}{c}\text { Market } \\
\text { Manipulation } \\
\text { Index }\end{array}$ & $\begin{array}{l}\text { Insider } \\
\text { Trading } \\
\text { Index }\end{array}$ & $\begin{array}{l}\text { Broker } \\
\text { Agency } \\
\text { Index }\end{array}$ \\
\hline \multicolumn{8}{|l|}{ English Legal Origin } \\
\hline Australia & $3(3)$ & $1(1)$ & $2(2)$ & $0(0)$ & $6(6)$ & $2(2)$ & $0(0)$ \\
\hline Bombay & $0(0)$ & $1(1)$ & $1(1)$ & $1(1)$ & $3(3)$ & $2(2)$ & $3(3)$ \\
\hline Canada & $7(7)$ & $2(2)$ & $3(3)$ & $0(0)$ & $12(12)$ & $2(2)$ & $1(1)$ \\
\hline Hong Kong & $3(3)$ & $2(2)$ & $1(1)$ & $1(1)$ & $7(7)$ & $0(0)$ & $0(0)$ \\
\hline India NSE & $3(3)$ & $1(1)$ & $1(1)$ & $1(1)$ & $6(6)$ & $3(3)$ & $3(3)$ \\
\hline London & $7(6)$ & $2(2)$ & $3(3)$ & $1(1)$ & $13(12)$ & $3(2)$ & $0(0)$ \\
\hline Malaysia & $0(0)$ & $0(0)$ & $1(1)$ & $1(1)$ & $2(2)$ & $7(7)$ & $2(2)$ \\
\hline NASDAQ & $5(5)$ & $1(1)$ & $3(3)$ & $2(2)$ & $11(11)$ & $10(10)$ & $5(5)$ \\
\hline NYSE & $6(6)$ & $2(2)$ & $3(3)$ & $2(2)$ & $13(13)$ & $7(7)$ & $3(3)$ \\
\hline Singapore & $3(3)$ & $1(1)$ & $2(2)$ & $1(1)$ & $7(7)$ & $2(2)$ & $2(2)$ \\
\hline Average English Legal Origin & $3.83(3.67)$ & $1.25(1.25)$ & $2.00(2.00)$ & $1.00(1.00)$ & $8.08(7.92)$ & $3.67(3.50)$ & $1.83(1.83)$ \\
\hline Median English Legal Origin & $3.00(3.00)$ & $1.00(1.00)$ & $2.00(2.00)$ & $1.00(1.00)$ & $7.00(7.00)$ & $3.00(2.00)$ & $2.00(2.00)$ \\
\hline \multicolumn{8}{|l|}{ German Legal Origin } \\
\hline Germany & $7(0)$ & $1(0)$ & $3(1)$ & $1(0)$ & $12(1)$ & $3(2)$ & $0(1)$ \\
\hline Korea & $4(4)$ & $2(2)$ & $2(2)$ & $1(1)$ & $9(9)$ & $3(3)$ & $2(2)$ \\
\hline Shanghai & $2(2)$ & $1(1)$ & $1(1)$ & $1(1)$ & $5(5)$ & $2(2)$ & $0(0)$ \\
\hline Shenzhen & $2(2)$ & $1(1)$ & $1(1)$ & $1(1)$ & $5(5)$ & $2(2)$ & $0(0)$ \\
\hline Switzerland & $7(2)$ & $1(1)$ & $3(1)$ & $1(1)$ & $12(5)$ & $3(2)$ & $1(1)$ \\
\hline Taiwan & $2(2)$ & $0(0)$ & $0(0)$ & $0(0)$ & $2(2)$ & $0(0)$ & $0(0)$ \\
\hline Tokyo & $1(1)$ & $0(0)$ & $1(1)$ & $0(0)$ & $2(2)$ & $1(1)$ & $0(0)$ \\
\hline Average German Legal Origin & $3.63(2.13)$ & $1.00(0.88)$ & $1.63(1.13)$ & $0.75(0.63)$ & $7.00(4.75)$ & $2.13(1.88)$ & $0.63(0.75)$ \\
\hline Median German Legal Origin & $3.00(2.00)$ & $1.00(1.00)$ & $1.50(1.00)$ & $1.00(1.00)$ & $7.00(5.00)$ & $2.50(2.00)$ & $0.00(0.50)$ \\
\hline \multicolumn{8}{|l|}{$\underline{\text { Scandinavian Legal Origin }}$} \\
\hline OMX & $7(2)$ & $1(1)$ & $3(2)$ & $1(1)$ & $12(6)$ & $5(4)$ & $2(2)$ \\
\hline Oslo & $7(2)$ & $1(1)$ & $3(1)$ & $1(0)$ & $12(4)$ & $4(3)$ & $0(0)$ \\
\hline Average Scandinavian Legal Origin & $7.00(2.00)$ & $1.00(1.00)$ & $3.00(1.50)$ & $1.00(0.50)$ & $12.00(5.00)$ & $4.50(3.50)$ & $1.00(1.00)$ \\
\hline Median Scandinavian Legal Origin & $7.00(2.00)$ & $1.00(1.00)$ & $3.00(1.50)$ & $1.00(0.50)$ & $12.00(5.00)$ & $4.50(3.50)$ & $1.00(1.00)$ \\
\hline
\end{tabular}


Table 2 (Continued)

Panel B:

\begin{tabular}{|c|c|c|c|c|c|c|c|}
\hline Tests of Means & $\begin{array}{c}\text { Price } \\
\text { Manipulation } \\
\text { Index }\end{array}$ & $\begin{array}{c}\text { Volume } \\
\text { Manipulation } \\
\text { Index }\end{array}$ & $\begin{array}{l}\text { Spoofing } \\
\text { Index }\end{array}$ & $\begin{array}{c}\text { False } \\
\text { Disclosure } \\
\text { Index }\end{array}$ & $\begin{array}{c}\text { Market } \\
\text { Manipulation } \\
\text { Index }\end{array}$ & $\begin{array}{c}\text { Insider } \\
\text { Trading } \\
\text { Index }\end{array}$ & $\begin{array}{c}\text { Broker } \\
\text { Agency } \\
\text { Index }\end{array}$ \\
\hline English versus Civil Law & $\begin{array}{c}-3.01 * * * \\
(16.07 * * *)\end{array}$ & $\begin{array}{c}5.74 * * * \\
\left(8.76^{* * *}\right)\end{array}$ & $\begin{array}{c}1.57 \\
\left(18.75^{* * *}\right)\end{array}$ & $\begin{array}{c}6.33^{* * *} \\
(13.37 * * *)\end{array}$ & $\begin{array}{c}0.33 \\
(17.44 * * *)\end{array}$ & $\begin{array}{c}7.90 * * * \\
(11.33 * * *)\end{array}$ & $\begin{array}{c}14.02^{* * *} \\
\left(14.81^{* * *}\right)\end{array}$ \\
\hline English versus German & $\begin{array}{c}1.32 \\
\left(14.87^{* * *}\right)\end{array}$ & $\begin{array}{c}5.09^{* * * *} \\
\left(8.25^{* * *}\right)\end{array}$ & $\begin{array}{c}5.66 * * * \\
(19.69 * * *)\end{array}$ & $\begin{array}{c}7.32 * * * \\
(11.94 * * *)\end{array}$ & $\begin{array}{c}4.07 * * * \\
(16.26 * * *)\end{array}$ & $\begin{array}{c}11.76^{* * *} \\
\left(14.25^{* * *}\right)\end{array}$ & $\begin{array}{c}14.67 * * \\
\left(15.26^{* * *}\right)\end{array}$ \\
\hline English versus Scandinavian & $\begin{array}{c}-29.75^{* * *} \\
\left(19.54^{* * *}\right)\end{array}$ & $\begin{array}{c}7.95^{* * *} \\
\left(9.13^{* * *}\right)\end{array}$ & $\begin{array}{l}-25.15^{* * *} \\
(8.61 * * *)\end{array}$ & $\begin{array}{c}0.00 \\
\left(9.71^{* * *}\right)\end{array}$ & $\begin{array}{c}-22.78 * * * \\
(17.14 * * *)\end{array}$ & $\begin{array}{c}-6.41 * * * \\
(0.00)\end{array}$ & $\begin{array}{c}6.55^{* *} \\
(7.53 * * *)\end{array}$ \\
\hline German versus Scandinavian & $\begin{array}{c}-29.06^{* * *} \\
\left(2.12^{* *}\right)\end{array}$ & $\begin{array}{c}0.00 \\
\left(-3.45^{* * *}\right)\end{array}$ & $\begin{array}{l}-25.96 * * * \\
\left(-6.90^{* * *}\right)\end{array}$ & $\begin{array}{c}-10.82^{* * *} * \\
(2.41 * *)\end{array}$ & $\begin{array}{c}-24.60 * * * \\
(-1.54)\end{array}$ & $\begin{array}{c}-30.57 * * * \\
(-25.60 * * *)\end{array}$ & $\begin{array}{l}-3.22 * * * \\
(-2.48 * *)\end{array}$ \\
\hline
\end{tabular}


Table 3.

\section{Descriptive Statistics}

This table presents statistics for the full sample of country-month observations in the data. The data span the months from January 2003 - June 2011 , and the exchanges listed in Table 2. Index from La Porta (1998, 2006), Jackson and Roe (2009) and DLLS (2008) are not available for China.

\begin{tabular}{|c|c|c|c|c|c|c|}
\hline & Mean & Median & $\begin{array}{l}\text { Standard } \\
\text { Deviation }\end{array}$ & Minimum & Maximum & $\begin{array}{l}\text { Number of } \\
\text { Observations }\end{array}$ \\
\hline Suspected Dislocating the EOD Price Cases & 36.56 & 15 & 86.03 & 0 & 1645 & 2196 \\
\hline $\begin{array}{l}\text { Total Trading Value Surrounding Per Suspected } \\
\text { Dislocating the EOD Price Case }\end{array}$ & 685637.8 & 142727 & 2408576 & 0 & $5.72 \mathrm{e}+07$ & 2196 \\
\hline HFT Dummy & 0.46 & 0 & 0.50 & 0 & 1 & 2196 \\
\hline Co-Location Dummy & 0.16 & 0 & 0.40 & 0 & 1 & 2196 \\
\hline Total Trading Rule Index & 18.54 & 18 & 9.27 & 4 & 37 & 2196 \\
\hline Surveillance & 18.54 & 14 & 13.93 & 3 & 41 & 2196 \\
\hline $\begin{array}{l}\text { Resource-based measures of public enforcement } \\
\text { (Jackson and Roe, 2009) }\end{array}$ & 20.52 & 12.53 & 19.42 & .43 & 77.74 & 1992 \\
\hline Public enforcement index (DLLS, 2008) & 0.47 & 0.5 & 0.42 & 0 & 1 & 1992 \\
\hline Rule of Law & 8.32 & 8.98 & 1.98 & 4.17 & 10 & 1992 \\
\hline Efficiency of the Judiciary & 9.08 & 10 & 1.36 & 6 & 10 & 1992 \\
\hline log(Market Capitalization) & 29.83 & 29.39 & 2.55 & 25.91 & 38.56 & 2178 \\
\hline $\log$ (Volume) & 23.12 & 23.27 & 1.81 & 15.60 & 27.10 & 2196 \\
\hline $\log$ (Number of Trades) & 26.75 & 26.77 & 2.90 & 19.37 & 32.81 & 2196 \\
\hline log(Average Market Trade Size) & 7.96 & 7.87 & 1.62 & 5.16 & 12.88 & 2196 \\
\hline $\log$ (Market Volatility) & -3.82 & -3.79 & 0.69 & -9.45 & -1.61 & 2174 \\
\hline $\log$ (GDP per capita) & 9.57 & 1.39 & 10.20 & 6.14 & 11.44 & 2196 \\
\hline
\end{tabular}


Table 4.

\section{Comparison Tests}

This table presents the comparison of mean and median tests for number of suspected dislocating the EOD price cases (Panel A) and total trading value surrounding per suspected dislocating the EOD price cause (Panel B) for the period January 2003 to December 2007. Market capitalization weighted mean and median are used for the test. The $* * *$ and $* * *$ denote significance at the $10 \%, 5 \%$ and $1 \%$ level, respectively.

\begin{tabular}{|c|c|c|c|c|}
\hline \multicolumn{5}{|c|}{ Panel A: Suspected Dislocating the EOD Price Cases } \\
\hline & \multicolumn{2}{|c|}{ All Countries } & \multicolumn{2}{|c|}{ HFT Countries } \\
\hline & $\begin{array}{c}\text { HFT } \\
\text { Countries }\end{array}$ & $\begin{array}{l}\text { Non-HFT } \\
\text { Countries }\end{array}$ & Post -HFT & Pre-HFT \\
\hline Group & 1 & 0 & 1 & 0 \\
\hline $\begin{array}{l}\text { Number of } \\
\text { Observations }\end{array}$ & 780 & 480 & 436 & 344 \\
\hline Mean & 3.541 & 0.635 & 1.052 & 6.697 \\
\hline $\begin{array}{l}\text { Standard } \\
\text { Deviation }\end{array}$ & 18.046 & 1.327 & 4.716 & 26.325 \\
\hline Median & 0.006 & 0.129 & 0.004 & 0.035 \\
\hline $\begin{array}{l}\text { Difference in } \\
\text { means }(0-1)\end{array}$ & \multicolumn{2}{|c|}{$-4.478^{* * *}$} & \multicolumn{2}{|c|}{$3.927 * * *$} \\
\hline $\begin{array}{l}\text { Difference in } \\
\text { medians }(0-1)\end{array}$ & \multicolumn{2}{|c|}{$11.638^{* * * *}$} & \multicolumn{2}{|c|}{$6.012 * * *$} \\
\hline
\end{tabular}

Panel B: Total Trading Value Surrounding Per Suspected Dislocating the EOD Price Case

\begin{tabular}{lcccc}
\hline & \multicolumn{2}{c}{ All Countries } & \multicolumn{2}{c}{ HFT Countries } \\
\hline & $\begin{array}{c}\text { HFT } \\
\text { Countries }\end{array}$ & $\begin{array}{c}\text { Non-HFT } \\
\text { Countries }\end{array}$ & Post -HFT & Pre-HFT \\
\hline Group & 1 & 0 & 1 & 0 \\
\hline $\begin{array}{l}\text { Number of } \\
\text { Observations }\end{array}$ & 780 & 480 & 436 & 344 \\
$\begin{array}{l}\text { Mean } \\
\text { Standard }\end{array}$ & 40586.67 & 118325.6 & 22465.07 & 63554.75 \\
$\begin{array}{l}\text { Deviation } \\
\text { Median }\end{array}$ & 183767.8 & 607398.7 & 122898.5 & 237899 \\
$\begin{array}{l}\text { Difference in } \\
\text { means (0-1) }\end{array}$ & 27.82 & 269.01 & 35.45 & 18.75 \\
$\begin{array}{l}\text { Difference in } \\
\text { medians (0-1) }\end{array}$ & \multicolumn{2}{c}{$2.728^{* * *}$} & & \multicolumn{2}{c}{$2.912^{* * *}$} \\
\hline
\end{tabular}


Table 5

Correlation matrix.

This Table presents Pearson Correlation coefficients for the full sample of exchange-months in the data. The *,** and $* * *$ indicate the correlations are statistically significant at the $10 \%, 5 \%$ and $1 \%$.
.

\begin{tabular}{|c|c|c|c|c|c|c|c|c|c|c|c|c|c|c|c|c|}
\hline & & (1) & (2) & (3) & (4) & (5) & (6) & (7) & (8) & (9) & (10) & (11) & (12) & (13) & (14) & (15) \\
\hline (1) & $\begin{array}{l}\text { Suspected } \\
\text { Dislocating the } \\
\text { EOD Price Cases } \\
\text { Total Trading }\end{array}$ & 1 & & & & & & & & & & & & & & \\
\hline (2) & $\begin{array}{l}\text { Value } \\
\text { Surrounding Per } \\
\text { Suspected } \\
\text { Dislocating the } \\
\text { EOD Price Case }\end{array}$ & -0.033 & 1 & & & & & & & & & & & & & \\
\hline (3) & HFT Dummy & $-0.0476^{*}$ & $0.0856^{* * *}$ & 1 & & & & & & & & & & & & \\
\hline (4) & $\begin{array}{l}\text { Co-Location } \\
\text { Dummy }\end{array}$ & 0.0101 & 0.0101 & $0.396^{* * *}$ & 1 & & & & & & & & & & & \\
\hline (5) & $\begin{array}{l}\text { Total Trading } \\
\text { Rule Index }\end{array}$ & 0.0087 & $0.0996^{* * *}$ & $0.345^{* * *}$ & $0.222^{* * *}$ & 1 & & & & & & & & & & \\
\hline (6) & $\begin{array}{l}\text { Surveillance } \\
\text { Resource-based } \\
\text { measures of }\end{array}$ & $-0.106 * * *$ & $0.109^{* * *}$ & $0.163^{* * *}$ & $0.148^{* * *}$ & $0.620^{* * *}$ & 1 & & & & & & & & & \\
\hline (7) & $\begin{array}{l}\text { public } \\
\text { enforcement } \\
\text { (Jackson and } \\
\text { Roe, 2009) }\end{array}$ & $-0.115^{* * *}$ & -0.0402 & $-0.214^{* * *}$ & $-0.0471^{*}$ & $0.120^{* * *}$ & $-0.0486^{*}$ & 1 & & & & & & & & \\
\hline (8) & $\begin{array}{l}\text { Public } \\
\text { enforcement } \\
\text { index (DLLS, } \\
\text { 2008) }\end{array}$ & $-0.0785 * * *$ & $0.0611^{* *}$ & $-0.0490^{*}$ & -0.00332 & $-0.0458^{*}$ & $-0.365 * * *$ & $0.110^{* * *}$ & 1 & & & & & & & \\
\hline (9) & $\begin{array}{l}\text { Efficiency of the } \\
\text { Judiciary }\end{array}$ & $-0.0493^{*}$ & $0.0508^{*}$ & $0.484^{* * *}$ & $0.121^{* * *}$ & $0.167^{* * *}$ & $-0.158^{* * *}$ & $0.345^{* * *}$ & -0.0131 & 1 & & & & & & \\
\hline (10) & Rule of Law & $-0.262^{* * *}$ & $0.0879 * * *$ & $0.532^{* * *}$ & $0.119^{* * *}$ & $0.197 * * *$ & $0.0987 * * *$ & $0.268^{* * *}$ & -0.0193 & $0.729 * * *$ & 1 & & & & & \\
\hline (11) & $\begin{array}{l}\text { log(Market } \\
\text { Capitalization) }\end{array}$ & $0.0995 * * *$ & 0.0262 & $-0.0793^{* * *}$ & -0.0293 & $-0.0621^{* *}$ & $0.250^{* * *}$ & $-0.371^{* * *}$ & $-0.483^{* * *}$ & $-0.335^{* * *}$ & $-0.399^{* * *}$ & 1 & & & & \\
\hline (12) & $\log$ (Volume) & 0.0317 & 0.00966 & $-0.230^{* * *}$ & $0.0800 * * *$ & 0.0127 & $0.219 * * *$ & $0.398 * * *$ & $-0.374^{* * *}$ & $-0.0701^{* *}$ & $-0.0806 * * *$ & $0.328^{* * *}$ & 1 & & & \\
\hline (13) & $\begin{array}{l}\log \text { (Number of } \\
\text { Trades) } \\
\log \text { (Average }\end{array}$ & $0.0584^{* *}$ & $0.0582^{* *}$ & $-0.165 * * *$ & 0.0147 & $0.0998^{* * *}$ & $0.419^{* * *}$ & $-0.242^{* * *}$ & $-0.370^{* * *}$ & $-0.515^{* * *}$ & $-0.431^{* * *}$ & $0.840^{* * *}$ & $0.580^{* * *}$ & 1 & & \\
\hline (14) & $\begin{array}{l}\text { Market Trade } \\
\text { Size) }\end{array}$ & $-0.210^{* * *}$ & $-0.0527^{*}$ & $-0.428^{* * *}$ & $-0.263^{* * *}$ & $-0.487 * * *$ & $-0.355^{* * *}$ & $0.570^{* * *}$ & -0.0398 & $0.215^{* * *}$ & $0.187^{* * *}$ & $-0.258^{* * *}$ & $0.390^{* * *}$ & $-0.216^{* * *}$ & 1 & \\
\hline (15) & $\begin{array}{l}\text { log (Market } \\
\text { Volatility) }\end{array}$ & $0.126^{* * *}$ & $-0.0663^{* *}$ & $-0.228^{* * *}$ & $-0.173^{* * *}$ & $0.0873^{* * *}$ & $-0.0811^{* * *}$ & $0.0630^{* *}$ & $-0.152^{* * *}$ & $-0.210^{* * *}$ & $-0.300^{* * *}$ & $0.203^{* * *}$ & $0.134^{* * *}$ & $0.234^{* * *}$ & -0.0328 & 1 \\
\hline (16) & $\begin{array}{l}\log \text { (GDP per } \\
\text { capita) }\end{array}$ & $-0.332^{* * *}$ & $0.114^{* * *}$ & $0.327^{* * *}$ & $0.168^{* * *}$ & $0.285^{* * *}$ & $0.295 * * *$ & $0.374^{* * *}$ & $-0.106^{* * *}$ & $0.359 * * *$ & $0.692 * * *$ & $-0.114^{* * *}$ & $0.323^{* * *}$ & $0.0709 * *$ & $0.262^{* * *}$ & $-0.173^{* * *}$ \\
\hline
\end{tabular}




\section{Table 6:}

\section{Regression Results}

This table presents Ordinary Least Square panel regressions of determinates of the number of suspected EOD price cases and the trading value surrounding each cases. Variables are as defined in Table 1. Standard errors are clustered by exchange and month for models 3 and 4, and clustered by year for Models 1, 2, and 5-8. Panel A presents regression results for the suspected dislocating the end of day (EOD) price cases. Panel B presents regression results for average trading value surrounding per suspected dislocating the EOD price case. Model 1 presents the results with the HFT dummy alone and Model 2 presents results with both HFT dummy and co-location dummy. Model 3 presents a regression result with market control variables. Model 4 presents a regression result with the Total Trading Rule Index from Cumming, et al. (2010). Model 5 presents the results with Public Enforcement Index from Jackson and Roe, (2009) and from Djankov, et al. (2008), Total Trading Rule Index from Cumming, et al. (2010), and surveillance index from Cumming and Johan (2008) with Efficiency of the judiciary index and rule of law index from LLSV $(1998,2006)$. Model 6 and Model 8 present the results with all index and control variables including and excluding data from the United States, respectively. Model 7 replicates the Model 5 without the data from the United States. The *,** and $* * *$ are statistically significant at the $10 \%, 5 \%$ and $1 \%$ level, respectively. T-statistics are in square brackets.

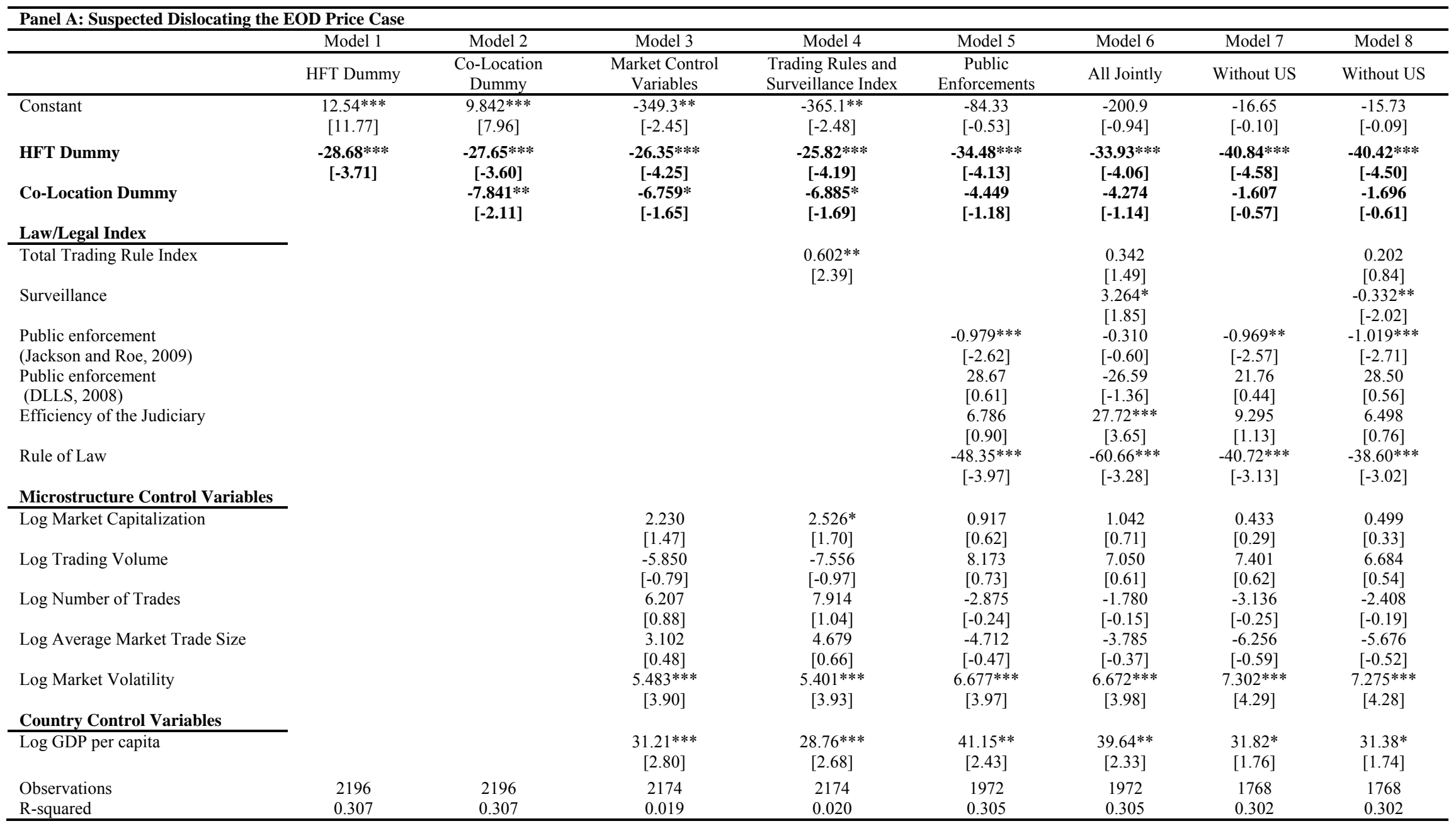




\begin{tabular}{|c|c|c|c|c|c|c|c|c|}
\hline & Model 1 & Model 2 & Model 3 & Model 4 & Model 5 & Model 6 & Model 7 & Model 8 \\
\hline & HFT Dummy & $\begin{array}{l}\text { Co-Location } \\
\text { Dummy }\end{array}$ & $\begin{array}{l}\text { Market Control } \\
\text { Variables }\end{array}$ & $\begin{array}{c}\text { Trading Rules } \\
\text { and Surveillance } \\
\text { Index }\end{array}$ & $\begin{array}{c}\text { Public } \\
\text { Enforcements }\end{array}$ & All Jointly & Without US & Without US \\
\hline Constant & $\begin{array}{c}433599.5^{* * *} \\
{[7.88]}\end{array}$ & $\begin{array}{c}248168.8^{* * * *} \\
{[6.15]}\end{array}$ & $\begin{array}{c}-11953472.4^{* * *} \\
{[-6.77]}\end{array}$ & $\begin{array}{c}-11508826.3 * * * \\
{[-7.18]}\end{array}$ & $\begin{array}{c}-12919095.2^{* * * *} \\
{[-4.97]}\end{array}$ & $\begin{array}{c}-13195920.8^{* * *} \\
{[-4.61]}\end{array}$ & $\begin{array}{c}-15383223.6^{* * *} \\
{[-5.87]}\end{array}$ & $\begin{array}{c}-16455144.0^{* * * *} \\
{[-5.65]}\end{array}$ \\
\hline HFT Dummy & $\begin{array}{r}-309885.6^{*} \\
{[-1.96]}\end{array}$ & $\begin{array}{c}-294162.7 * \\
{[-1.74]}\end{array}$ & $\begin{array}{c}-315961.9 * \\
{[-1.86]}\end{array}$ & $\begin{array}{l}-330926.0 * * \\
{[-2.03]}\end{array}$ & $\begin{array}{c}-372915.5 * * \\
{[-2.34]}\end{array}$ & $\begin{array}{c}-400167.5 * * * \\
{[-2.66]}\end{array}$ & $\begin{array}{c}-338487.0 * \\
{[-1.94]}\end{array}$ & $\begin{array}{c}-361838.9 * * \\
{[-2.27]}\end{array}$ \\
\hline $\begin{array}{l}\text { Co-Location Dummy } \\
\text { Law/Legal Index }\end{array}$ & & $\begin{array}{c}-119521.4 \\
{[-0.51]}\end{array}$ & $\begin{array}{c}-102321.3 \\
{[-0.42]}\end{array}$ & $\begin{array}{c}-98787.0 \\
{[-0.41]}\end{array}$ & $\begin{array}{c}51853.8 \\
{[0.20]}\end{array}$ & $\begin{array}{c}43220.9 \\
{[0.16]}\end{array}$ & $\begin{array}{c}-11787.4 \\
{[-0.04]}\end{array}$ & $\begin{array}{c}-6859.5 \\
{[-0.02]}\end{array}$ \\
\hline Total Trading Rule Index & & & & $\begin{array}{c}-16909.8 \\
{[-0.54]}\end{array}$ & & $\begin{array}{c}-16978.6 \\
{[-0.54]}\end{array}$ & & $\begin{array}{c}-11100.3 \\
{[-0.36]}\end{array}$ \\
\hline Surveillance & & & & & & $\begin{array}{c}28887.1 \\
{[1.02]}\end{array}$ & & $\begin{array}{c}50403.9^{* * * *} \\
{[3.39]}\end{array}$ \\
\hline $\begin{array}{l}\text { Public enforcement } \\
\text { (Jackson and Roe, 2009) }\end{array}$ & & & & & $\begin{array}{l}-7739.5 \\
{[-0.55]}\end{array}$ & $\begin{array}{r}-3228.0 \\
{[-0.21]}\end{array}$ & $\begin{array}{l}-5222.9 \\
{[-0.37]}\end{array}$ & $\begin{array}{l}3871.6 \\
{[0.29]}\end{array}$ \\
\hline $\begin{array}{l}\text { Public enforcement } \\
\text { (DLLS, 2008) }\end{array}$ & & & & & $\begin{array}{c}3274330.2 * * * \\
{[3.14]}\end{array}$ & $\begin{array}{c}2716146.4^{* * *} \\
{[2.74]}\end{array}$ & $\begin{array}{c}3733663.3 * * * \\
{[3.45]}\end{array}$ & $\begin{array}{c}2807282.1 * * * \\
{[2.87]}\end{array}$ \\
\hline Efficiency of the Judiciary & & & & & $\begin{array}{c}-315559.5^{*} \\
{[-1.69]}\end{array}$ & $\begin{array}{c}-83834.9 \\
{[-0.40]}\end{array}$ & $\begin{array}{c}-433472.9 * * \\
{[-2.10]}\end{array}$ & $\begin{array}{c}-65680.0 \\
{[-0.33]}\end{array}$ \\
\hline Rule of Law & & & & & $\begin{array}{c}163627.2 \\
{[0.46]}\end{array}$ & $\begin{array}{c}-46321.7 \\
{[-0.09]}\end{array}$ & $\begin{array}{c}-90950.7 \\
{[-0.22]}\end{array}$ & $\begin{array}{c}-345725.3 \\
{[-0.71]}\end{array}$ \\
\hline \multicolumn{9}{|l|}{$\begin{array}{l}\text { Microstructure Control } \\
\text { Variables }\end{array}$} \\
\hline Log Market Capitalization & & & $\begin{array}{l}102872.8^{* *} \\
{[2.14]}\end{array}$ & $\begin{array}{c}94548.6^{* *} \\
{[2.15]}\end{array}$ & $\begin{array}{c}53711.8 \\
{[0.97]}\end{array}$ & $\begin{array}{c}47530.7 \\
{[0.91]}\end{array}$ & $\begin{array}{c}35087.7 \\
{[0.62]}\end{array}$ & $\begin{array}{c}31466.7 \\
{[0.58]}\end{array}$ \\
\hline Log Trading Volume & & & $\begin{array}{l}6690.1 \\
{[0.05]}\end{array}$ & $\begin{array}{c}54605.1 \\
{[0.43]}\end{array}$ & $\begin{array}{c}259242.5 \\
{[1.34]}\end{array}$ & $\begin{array}{c}314944.7^{*} \\
{[1.91]}\end{array}$ & $\begin{array}{c}194323.9 \\
{[0.97]}\end{array}$ & $\begin{array}{c}233726.2 \\
{[1.38]}\end{array}$ \\
\hline Log Number of Trades & & & $\begin{array}{c}365927.3 * * * \\
{[3.12]}\end{array}$ & $\begin{array}{c}317979.8^{* *} \\
{[2.25]}\end{array}$ & $\begin{array}{c}217675.8 \\
{[1.30]}\end{array}$ & $\begin{array}{c}163376.0 \\
{[0.93]}\end{array}$ & $\begin{array}{c}346702.9^{* *} \\
{[1.98]}\end{array}$ & $\begin{array}{c}306699.6^{*} \\
{[1.70]}\end{array}$ \\
\hline Log Average Market Trade Size & & & $\begin{array}{c}-167806.9 * \\
{[-1.75]}\end{array}$ & $\begin{array}{c}-212098.7 * * \\
{[-2.22]}\end{array}$ & $\begin{array}{c}-279650.8^{* * * *} \\
{[-2.62]}\end{array}$ & $\begin{array}{c}-325614.9 * * * \\
{[-2.76]}\end{array}$ & $\begin{array}{c}-251224.0 * * \\
{[-2.24]}\end{array}$ & $\begin{array}{c}-283091.0 * * \\
{[-2.31]}\end{array}$ \\
\hline Log Market Volatility & & & $\begin{array}{c}27626.2 \\
{[0.19]}\end{array}$ & $\begin{array}{c}29946.1 \\
{[0.21]}\end{array}$ & $\begin{array}{c}146525.6 \\
{[0.88]}\end{array}$ & $\begin{array}{c}146777.2 \\
{[0.89]}\end{array}$ & $\begin{array}{c}151474.3 \\
{[0.88]}\end{array}$ & $\begin{array}{c}152944.9 \\
{[0.90]}\end{array}$ \\
\hline \multicolumn{9}{|l|}{ Country Control Variables } \\
\hline Log GDP per capita & & & $\begin{array}{c}128714.7 \\
{[0.50]}\end{array}$ & $\begin{array}{c}197542.6 \\
{[0.65]}\end{array}$ & $\begin{array}{c}286352.5 \\
{[0.61]}\end{array}$ & $\begin{array}{c}360963.2 \\
{[0.69]}\end{array}$ & $\begin{array}{c}661156.5 \\
{[1.17]}\end{array}$ & $\begin{array}{c}684807.9 \\
{[1.15]}\end{array}$ \\
\hline Observations & 2196 & 2196 & 2174 & 2174 & 1972 & 1972 & 1768 & 1768 \\
\hline R-squared & 0.071 & 0.071 & 0.017 & 0.017 & 0.076 & 0.076 & 0.078 & 0.078 \\
\hline
\end{tabular}


Table 7:

Robustness Check with winsorized Dependent Variables.

This table presents Ordinary Least Square panel regressions of determinates of the number of suspected EOD price cases and the trading value surrounding each cases. Variables are as defined in Table 1 and both dependent variables are winsorized at the $99 \%$ level. Standard errors are clustered by year. Model definitions can be found in Table 6 . The *,** and *** are statistically significant at the $10 \%, 5 \%$ and $1 \%$ level, respectively. T-statistics are in parentheses.

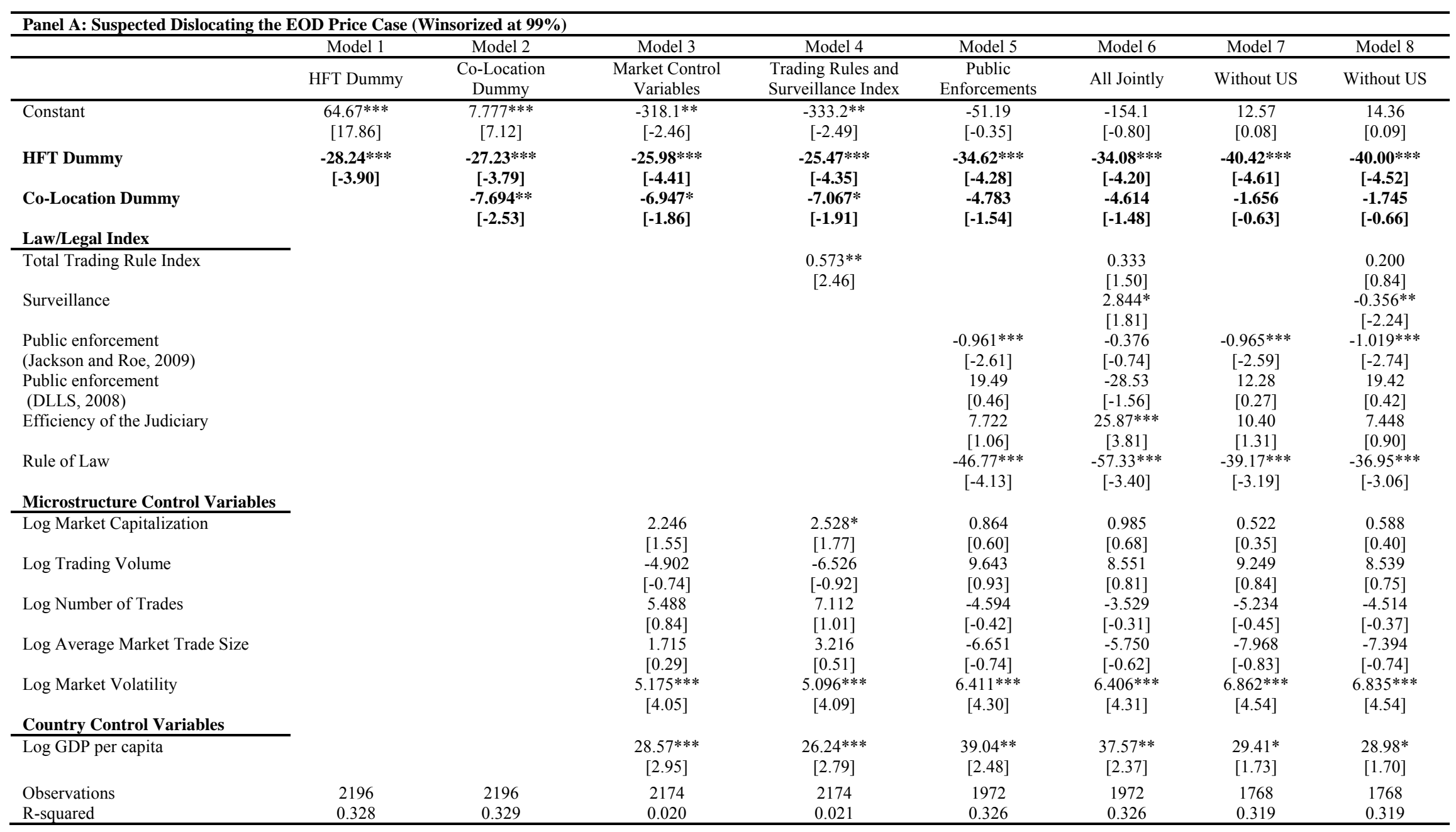




\begin{tabular}{|c|c|c|c|c|c|c|c|c|}
\hline & Model 1 & Model 2 & Model 3 & Model 4 & Model 5 & Model 6 & Model 7 & Model 8 \\
\hline & HFT Dummy & $\begin{array}{l}\text { Co-Location } \\
\text { Dummy }\end{array}$ & $\begin{array}{l}\text { Market Control } \\
\text { Variables }\end{array}$ & $\begin{array}{c}\text { Trading Rules } \\
\text { and Surveillance } \\
\text { Index } \\
\end{array}$ & $\begin{array}{c}\text { Public } \\
\text { Enforcements }\end{array}$ & All Jointly & Without US & Without US \\
\hline Constant & $\begin{array}{c}236575.7^{* * *} \\
{[6.87]}\end{array}$ & $\begin{array}{c}1007244.1^{* * * *} \\
{[6.09]}\end{array}$ & $\begin{array}{c}-11169618.2 * * * \\
{[-6.70]}\end{array}$ & $\begin{array}{c}-10714739.1 * * * \\
{[-7.20]}\end{array}$ & $\begin{array}{c}-11131917.2^{* * * *} \\
{[-5.87]}\end{array}$ & $\begin{array}{c}-11215271.0^{* * *} \\
{[-5.28]}\end{array}$ & $\begin{array}{c}-13272601.1^{* * * *} \\
{[-6.98]}\end{array}$ & $\begin{array}{c}-14273774.3^{* * * *} \\
{[-6.60]}\end{array}$ \\
\hline HFT Dummy & $\begin{array}{c}-292493.2 * * \\
{[-2.14]}\end{array}$ & $\begin{array}{c}-291528.1 * * \\
{[-2.03]}\end{array}$ & $\begin{array}{c}-309515.9 * * \\
{[-1.98]}\end{array}$ & $\begin{array}{c}-324824.4^{* *} \\
{[-2.17]}\end{array}$ & $\begin{array}{c}-370406.4^{* *} \\
{[-2.56]}\end{array}$ & $\begin{array}{c}-396825.8^{* * *} \\
{[-2.90]}\end{array}$ & $\begin{array}{c}-341339.2^{* *} \\
{[-2.22]}\end{array}$ & $\begin{array}{c}-363303.2 * * \\
{[-2.56]}\end{array}$ \\
\hline Co-Location Dummy & & $\begin{array}{l}-7336.8 \\
{[-0.04]}\end{array}$ & $\begin{array}{c}15128.3 \\
{[0.08]}\end{array}$ & $\begin{array}{c}18744.0 \\
{[0.10]}\end{array}$ & $\begin{array}{c}170329.6 \\
{[0.88]}\end{array}$ & $\begin{array}{c}161960.5 \\
{[0.83]}\end{array}$ & $\begin{array}{c}104253.2 \\
{[0.44]}\end{array}$ & $\begin{array}{c}108888.3 \\
{[0.46]}\end{array}$ \\
\hline \multicolumn{9}{|l|}{ Law/Legal Index } \\
\hline Total Trading Rule Index & & & & $\begin{array}{c}-17298.9 \\
{[-0.68]}\end{array}$ & & $\begin{array}{c}-16459.8 \\
{[-0.63]}\end{array}$ & & $\begin{array}{c}-10440.6 \\
{[-0.41]}\end{array}$ \\
\hline Surveillance & & & & & & $\begin{array}{c}22177.8 \\
{[0.99]}\end{array}$ & & $\begin{array}{c}47186.6^{* * *} \\
{[3.93]}\end{array}$ \\
\hline $\begin{array}{l}\text { Public enforcement } \\
\text { (Jackson and Roe, 2009) }\end{array}$ & & & & & $\begin{array}{l}-8722.0 \\
{[-0.63]}\end{array}$ & $\begin{array}{l}-5498.9 \\
{[-0.37]}\end{array}$ & $\begin{array}{l}-6470.2 \\
{[-0.47]}\end{array}$ & $\begin{array}{l}2040.0 \\
{[0.16]}\end{array}$ \\
\hline $\begin{array}{l}\text { Public enforcement } \\
\text { (DLLS, 2008) }\end{array}$ & & & & & $\begin{array}{c}2718959.5^{* * *} \\
{[3.25]}\end{array}$ & $\begin{array}{c}2278579.1^{* * * *} \\
{[2.58]}\end{array}$ & $\begin{array}{c}3127684.9^{* * *} \\
{[3.64]}\end{array}$ & $\begin{array}{c}2260194.6^{* * *} \\
{[2.68]}\end{array}$ \\
\hline Efficiency of the Judiciary & & & & & $\begin{array}{c}-245064.8 \\
{[-1.51]}\end{array}$ & $\begin{array}{c}-59197.3 \\
{[-0.34]}\end{array}$ & $\begin{array}{c}-351627.6^{* *} \\
{[-2.01]}\end{array}$ & $\begin{array}{r}-7169.1 \\
{[-0.04]}\end{array}$ \\
\hline Rule of Law & & & & & $\begin{array}{c}76954.9 \\
{[0.27]}\end{array}$ & $\begin{array}{c}-101509.9 \\
{[-0.24]}\end{array}$ & $\begin{array}{c}-161278.0 \\
{[-0.47]}\end{array}$ & $\begin{array}{c}-399956.9 \\
{[-0.99]}\end{array}$ \\
\hline \multicolumn{9}{|l|}{$\begin{array}{l}\text { Microstructure Control } \\
\text { Variables }\end{array}$} \\
\hline Log Market Capitalization & & & $\begin{array}{c}97399.6 * * \\
{[2.16]}\end{array}$ & $\begin{array}{c}88883.8 * * \\
{[2.22]}\end{array}$ & $\begin{array}{c}45583.5 \\
{[0.85]}\end{array}$ & $\begin{array}{c}39591.2 \\
{[0.78]}\end{array}$ & $\begin{array}{c}28084.8 \\
{[0.51]}\end{array}$ & $\begin{array}{c}24679.0 \\
{[0.47]}\end{array}$ \\
\hline Log Trading Volume & & & $\begin{array}{c}-11776.5 \\
{[-0.10]}\end{array}$ & $\begin{array}{c}37241.3 \\
{[0.32]}\end{array}$ & $\begin{array}{c}250079.1 \\
{[1.54]}\end{array}$ & $\begin{array}{c}304079.3^{* *} \\
{[1.99]}\end{array}$ & $\begin{array}{c}180744.9 \\
{[1.09]}\end{array}$ & $\begin{array}{c}217805.4 \\
{[1.39]}\end{array}$ \\
\hline Log Number of Trades & & & $\begin{array}{c}330305.0^{* * * *} \\
{[3.13]}\end{array}$ & $\begin{array}{c}281254.0^{* *} \\
{[2.32]}\end{array}$ & $\begin{array}{c}154791.1 \\
{[1.17]}\end{array}$ & $\begin{array}{c}102150.3 \\
{[0.68]}\end{array}$ & $\begin{array}{c}274799.8^{* *} \\
{[2.00]}\end{array}$ & $\begin{array}{c}237173.9 \\
{[1.51]}\end{array}$ \\
\hline Log Average Market Trade Size & & & $\begin{array}{c}-130382.3 \\
{[-1.54]}\end{array}$ & $\begin{array}{c}-175693.5^{* *} \\
{[-2.05]}\end{array}$ & $\begin{array}{c}-249051.9^{* * *} \\
{[-2.78]}\end{array}$ & $\begin{array}{c}-293611.6^{* * * *} \\
{[-2.80]}\end{array}$ & $\begin{array}{c}-216797.0^{* *} \\
{[-2.36]}\end{array}$ & $\begin{array}{c}-246770.0^{* *} \\
{[-2.28]}\end{array}$ \\
\hline Log Market Volatility & & & $\begin{array}{c}51963.2 \\
{[0.42]}\end{array}$ & $\begin{array}{c}54336.5 \\
{[0.45]}\end{array}$ & $\begin{array}{c}162541.1 \\
{[1.10]}\end{array}$ & $\begin{array}{c}162785.1 \\
{[1.11]}\end{array}$ & $\begin{array}{c}162137.7 \\
{[1.07]}\end{array}$ & $\begin{array}{c}163520.9 \\
{[1.09]}\end{array}$ \\
\hline \multicolumn{9}{|l|}{ Country Control Variables } \\
\hline Log GDP per capita & & & $\begin{array}{c}179912.7 \\
{[0.97]}\end{array}$ & $\begin{array}{c}250324.7 \\
{[1.20]}\end{array}$ & $\begin{array}{c}338863.3 \\
{[0.96]}\end{array}$ & $\begin{array}{c}411194.3 \\
{[1.02]}\end{array}$ & $\begin{array}{c}686826.9 \\
{[1.59]}\end{array}$ & $\begin{array}{c}709072.6 \\
{[1.54]}\end{array}$ \\
\hline Observations & 2196 & 2196 & 2174 & 2174 & 1972 & 1972 & 1768 & 1768 \\
\hline R-squared & 0.093 & 0.093 & 0.020 & 0.021 & 0.099 & 0.100 & 0.100 & 0.100 \\
\hline
\end{tabular}




\begin{tabular}{|c|c|c|c|c|c|c|c|c|}
\hline & Model 1 & Model 2 & Model 3 & Model 4 & Model 5 & Model 6 & Model 7 & Model 8 \\
\hline & $\begin{array}{l}\text { Difference-in- } \\
\text { difference }\end{array}$ & $\begin{array}{l}\text { Co-Location } \\
\text { Dummy }\end{array}$ & $\begin{array}{l}\text { Market Control } \\
\text { Variables }\end{array}$ & $\begin{array}{c}\text { Trading Rules } \\
\text { and Surveillance } \\
\text { Index }\end{array}$ & $\begin{array}{c}\text { Public } \\
\text { Enforcements }\end{array}$ & All Jointly & Without US & Without US \\
\hline Constant & $\begin{array}{c}236575.7^{* * * *} \\
{[6.87]}\end{array}$ & $\begin{array}{c}1007244.1^{* * * *} \\
{[6.09]}\end{array}$ & $\begin{array}{c}-11929326.5^{* * *} \\
{[-4.06]}\end{array}$ & $\begin{array}{c}-9463892.7^{* * * *} \\
{[-5.48]}\end{array}$ & $\begin{array}{c}-11131917.2^{* * *} \\
{[-5.87]}\end{array}$ & $\begin{array}{c}-11215271.0^{* * *} \\
{[-5.28]}\end{array}$ & $\begin{array}{c}-13272601.1^{* * *} \\
{[-6.98]}\end{array}$ & $\begin{array}{c}-14273774.3^{* * *} \\
{[-6.60]}\end{array}$ \\
\hline HFT Dummy & $\begin{array}{c}-292493.2 * * \\
{[-2.14]}\end{array}$ & $\begin{array}{c}-291528.1^{* *} \\
{[-2.03]}\end{array}$ & $\begin{array}{c}-364591.8 * * \\
{[-2.56]}\end{array}$ & $\begin{array}{c}-396825.8 * * * \\
{[-2.90]}\end{array}$ & $\begin{array}{c}-370406.4 * * \\
{[-2.56]}\end{array}$ & $\begin{array}{c}-396825.8 * * * \\
{[-2.90]}\end{array}$ & $\begin{array}{c}-341339.2 * * \\
{[-2.22]}\end{array}$ & $\begin{array}{c}-363303.2^{* *} \\
{[-2.56]}\end{array}$ \\
\hline Co-Location Dummy & & $\begin{array}{c}-7336.8 \\
{[-0.04]}\end{array}$ & $\begin{array}{c}104530.0 \\
{[0.56]}\end{array}$ & $\begin{array}{c}161960.5 \\
{[0.83]}\end{array}$ & $\begin{array}{c}170329.6 \\
{[0.88]}\end{array}$ & $\begin{array}{c}161960.5 \\
{[0.83]}\end{array}$ & $\begin{array}{c}104253.2 \\
{[0.44]}\end{array}$ & $\begin{array}{c}108888.3 \\
{[0.46]}\end{array}$ \\
\hline Total Trading Rule Index & & & & $\begin{array}{c}-16459.8 \\
{[-0.63]}\end{array}$ & & $\begin{array}{c}-16459.8 \\
{[-0.63]}\end{array}$ & & $\begin{array}{c}-10440.6 \\
{[-0.41]}\end{array}$ \\
\hline Surveillance & & & & $\begin{array}{c}27188.0 \\
{[1.14]}\end{array}$ & & $\begin{array}{c}22177.8 \\
{[0.99]}\end{array}$ & & $\begin{array}{c}47186.6^{* * * *} \\
{[3.93]}\end{array}$ \\
\hline $\begin{array}{l}\text { Public enforcement } \\
\text { (Jackson and Roe, 2009) }\end{array}$ & & & & & $\begin{array}{c}-8722.0 \\
{[-0.63]}\end{array}$ & $\begin{array}{l}-5498.9 \\
{[-0.37]}\end{array}$ & $\begin{array}{l}-6470.2 \\
{[-0.47]}\end{array}$ & $\begin{array}{l}2040.0 \\
{[0.16]}\end{array}$ \\
\hline $\begin{array}{l}\text { Public enforcement } \\
\text { (DLLS, 2008) }\end{array}$ & & & & & $\begin{array}{c}2718959.5^{* * *} \\
{[3.25]}\end{array}$ & $\begin{array}{c}2278579.1 * * * \\
{[2.58]}\end{array}$ & $\begin{array}{c}3127684.9^{* * *} \\
{[3.64]}\end{array}$ & $\begin{array}{c}2260194.6^{* * *} \\
{[2.68]}\end{array}$ \\
\hline Efficiency of the Judiciary & & & & $\begin{array}{c}24422.6 \\
{[0.16]}\end{array}$ & $\begin{array}{c}-245064.8 \\
{[-1.51]}\end{array}$ & $\begin{array}{c}-59197.3 \\
{[-0.34]}\end{array}$ & $\begin{array}{c}-351627.6^{* *} \\
{[-2.01]}\end{array}$ & $\begin{array}{r}-7169.1 \\
{[-0.04]}\end{array}$ \\
\hline Rule of Law & & & & $\begin{array}{c}-393869.4 \\
{[-1.34]}\end{array}$ & $\begin{array}{c}76954.9 \\
{[0.27]}\end{array}$ & $\begin{array}{c}-101509.9 \\
{[-0.24]}\end{array}$ & $\begin{array}{c}-161278.0 \\
{[-0.47]}\end{array}$ & $\begin{array}{c}-399956.9 \\
{[-0.99]}\end{array}$ \\
\hline \multicolumn{9}{|l|}{$\begin{array}{l}\text { Microstructure Control } \\
\text { Variables }\end{array}$} \\
\hline Log Market Capitalization & & & $\begin{array}{c}74070.7 \\
{[1.56]}\end{array}$ & $\begin{array}{c}39591.2 \\
{[0.78]}\end{array}$ & $\begin{array}{c}45583.5 \\
{[0.85]}\end{array}$ & $\begin{array}{c}39591.2 \\
{[0.78]}\end{array}$ & $\begin{array}{c}28084.8 \\
{[0.51]}\end{array}$ & $\begin{array}{c}24679.0 \\
{[0.47]}\end{array}$ \\
\hline Log Trading Volume & & & $\begin{array}{c}310090.6^{* *} \\
{[2.07]}\end{array}$ & $\begin{array}{c}304079.3^{* *} \\
{[1.99]}\end{array}$ & $\begin{array}{c}250079.1 \\
{[1.54]}\end{array}$ & $\begin{array}{c}304079.3^{* *} \\
{[1.99]}\end{array}$ & $\begin{array}{c}180744.9 \\
{[1.09]}\end{array}$ & $\begin{array}{c}217805.4 \\
{[1.39]}\end{array}$ \\
\hline Log Number of Trades & & & $\begin{array}{c}90024.5 \\
{[0.80]}\end{array}$ & $\begin{array}{c}102150.3 \\
{[0.68]}\end{array}$ & $\begin{array}{c}154791.1 \\
{[1.17]}\end{array}$ & $\begin{array}{c}102150.3 \\
{[0.68]}\end{array}$ & $\begin{array}{c}274799.8^{* *} \\
{[2.00]}\end{array}$ & $\begin{array}{c}237173.9 \\
{[1.51]}\end{array}$ \\
\hline Log Average Market Trade Size & & & $\begin{array}{c}-286721.7 * * * \\
{[-3.54]}\end{array}$ & $\begin{array}{c}-293611.6^{* * *} \\
{[-2.80]}\end{array}$ & $\begin{array}{c}-249051.9^{* * * *} \\
{[-2.78]}\end{array}$ & $\begin{array}{c}-293611.6^{* * *} \\
{[-2.80]}\end{array}$ & $\begin{array}{c}-216797.0 * * \\
{[-2.36]}\end{array}$ & $\begin{array}{c}-246770.0 * * \\
{[-2.28]}\end{array}$ \\
\hline Log Market Volatility & & & $\begin{array}{c}103384.8 \\
{[0.75]}\end{array}$ & $\begin{array}{c}162785.1 \\
{[1.11]}\end{array}$ & $\begin{array}{c}162541.1 \\
{[1.10]}\end{array}$ & $\begin{array}{c}162785.1 \\
{[1.11]}\end{array}$ & $\begin{array}{c}162137.7 \\
{[1.07]}\end{array}$ & $\begin{array}{c}163520.9 \\
{[1.09]}\end{array}$ \\
\hline \multicolumn{9}{|l|}{ Country Control Variables } \\
\hline Log GDP per capita & & & $\begin{array}{c}540272.9^{*} \\
{[1.75]}\end{array}$ & $\begin{array}{c}411194.3 \\
{[1.02]}\end{array}$ & $\begin{array}{c}338863.3 \\
{[0.96]}\end{array}$ & $\begin{array}{c}411194.3 \\
{[1.02]}\end{array}$ & $\begin{array}{c}686826.9 \\
{[1.59]}\end{array}$ & $\begin{array}{c}709072.6 \\
{[1.54]}\end{array}$ \\
\hline $\begin{array}{l}\text { Observations } \\
\text { R-squared }\end{array}$ & $\begin{array}{l}2196 \\
0.093\end{array}$ & $\begin{array}{l}2196 \\
0.093\end{array}$ & $\begin{array}{l}2174 \\
0.106\end{array}$ & $\begin{array}{l}1972 \\
0.100\end{array}$ & $\begin{array}{l}1972 \\
0.099\end{array}$ & $\begin{array}{c}1972 \\
0.100\end{array}$ & $\begin{array}{l}1768 \\
0.100\end{array}$ & $\begin{array}{l}1768 \\
0.100\end{array}$ \\
\hline
\end{tabular}


Table 8

Robustness Checks with Alternative Dependent Variables

This table presents Ordinary Least Square panel regressions of determinates of the number of suspected EOD price cases and the trading value surrounding each cases. Both dependent variables are either measured at the end of each month or measured with matching option expire date. Variables are as defined in Table 1 and regression models are as defined in Table 6 . Standard errors are clustered by year. The *, ** and *** are statistically significant at the $10 \%, 5 \%$ and $1 \%$ level, respectively. T-statistics are in parentheses.

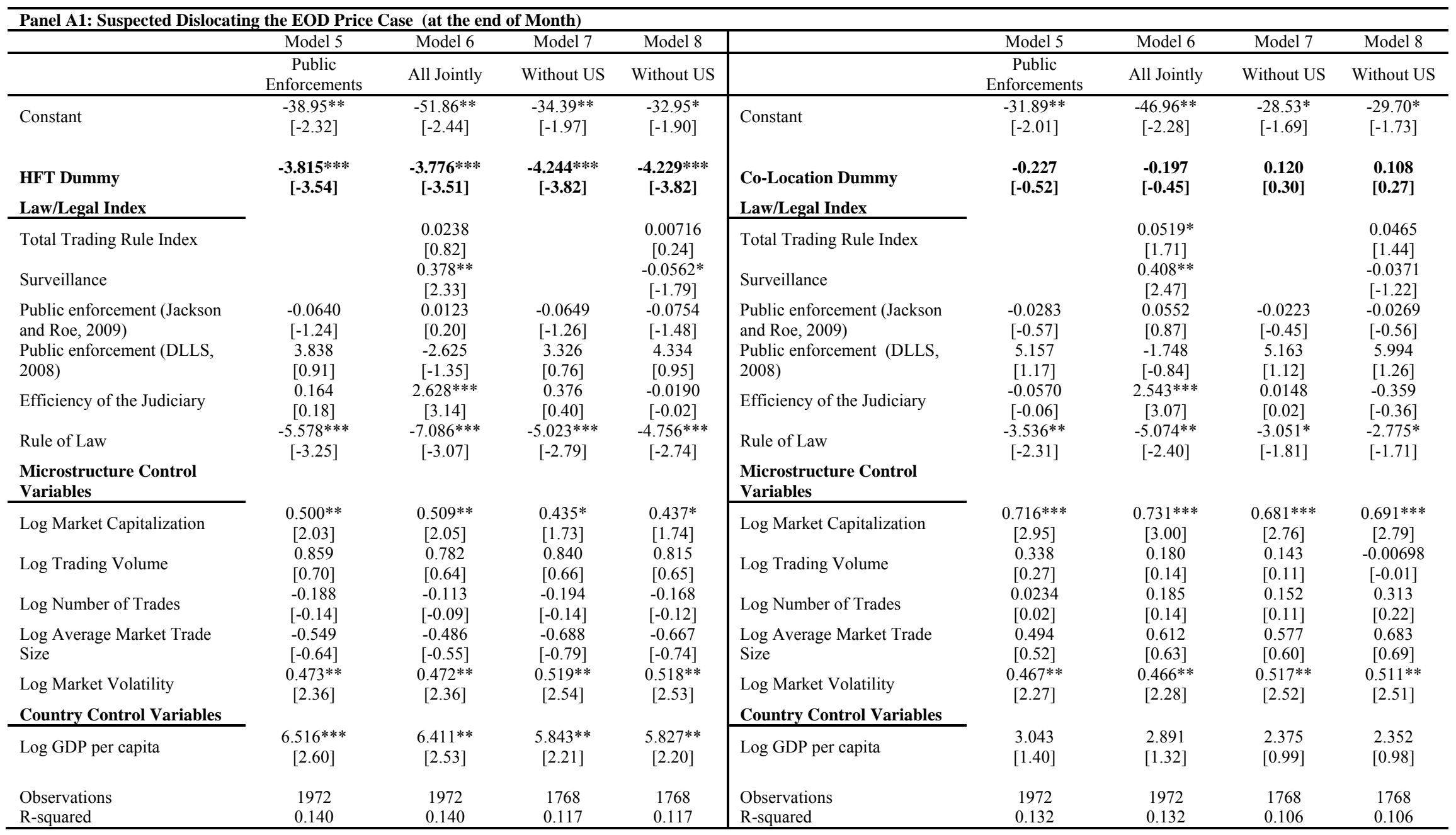




\begin{tabular}{|c|c|c|c|c|c|c|c|c|c|}
\hline & Model 5 & Model 6 & Model 7 & Model 8 & & Model 5 & Model 6 & Model 7 & Model 8 \\
\hline & $\begin{array}{c}\text { Public } \\
\text { Enforcements } \\
\end{array}$ & All Jointly & Without US & Without US & & $\begin{array}{c}\text { Public } \\
\text { Enforcements }\end{array}$ & All Jointly & Without US & Without US \\
\hline Constant & $\begin{array}{c}- \\
649735937.5^{* *} \\
{[-2.22]}\end{array}$ & $\begin{array}{c}- \\
1.00560 \mathrm{e}+09 * \\
* \\
{[-2.45]}\end{array}$ & $\begin{array}{c}-613067324.0^{*} \\
{[-1.85]}\end{array}$ & $\begin{array}{c}- \\
645690012.6^{*} \\
{[-1.78]}\end{array}$ & Constant & $\begin{array}{c}-568734083.7^{*} \\
{[-1.93]}\end{array}$ & $\begin{array}{c}- \\
939396554.9 * \\
* \\
{[-2.25]}\end{array}$ & $\begin{array}{c}-569487706.5^{*} \\
{[-1.72]}\end{array}$ & $\begin{array}{c}626666343.3^{*} \\
{[-1.72]}\end{array}$ \\
\hline $\begin{array}{l}\text { HFT Dummy } \\
\text { Law/Legal Index }\end{array}$ & $\begin{array}{c}-37517189.7 * * \\
{[-2.46]}\end{array}$ & $\begin{array}{c}-37032775.1^{* *} \\
{[-2.32]}\end{array}$ & $\begin{array}{c}-41169193.1 * * \\
{[-2.54]}\end{array}$ & $\begin{array}{c}- \\
41009086.0 * * \\
{[-2.35]}\end{array}$ & $\begin{array}{l}\text { Co-Location Dummy } \\
\text { Law/Legal Index }\end{array}$ & $\begin{array}{c}-23604183.6 \\
{[-1.08]}\end{array}$ & $\begin{array}{c}-23309004.2 \\
{[-1.05]}\end{array}$ & $\begin{array}{c}-25810104.5 \\
{[-1.17]}\end{array}$ & $\begin{array}{c}-25938765.5 \\
{[-1.19]}\end{array}$ \\
\hline $\begin{array}{l}\text { Total Trading Rule } \\
\text { Index }\end{array}$ & & $\begin{array}{c}295889.3 \\
{[0.21]}\end{array}$ & & $\begin{array}{c}77607.5 \\
{[0.05]}\end{array}$ & $\begin{array}{l}\text { Total Trading Rule } \\
\text { Index }\end{array}$ & & $\begin{array}{c}499277.4 \\
{[0.35]}\end{array}$ & & $\begin{array}{c}492833.5 \\
{[0.30]}\end{array}$ \\
\hline Surveillance & & $\begin{array}{c}10858834.2 * * \\
* \\
{[2.68]}\end{array}$ & & $\begin{array}{c}911406.4 \\
{[0.57]}\end{array}$ & Surveillance & & $\begin{array}{c}11033602.5^{* *} \\
* \\
{[2.73]}\end{array}$ & & $\begin{array}{c}1018467.3 \\
{[0.66]}\end{array}$ \\
\hline Public enforcement & $\begin{array}{c}4734310.1^{* *} \\
{[2.02]}\end{array}$ & $\begin{array}{c}6898372.4 * * \\
{[2.25]}\end{array}$ & $\begin{array}{l}4856329.3^{* *} \\
{[2.00]}\end{array}$ & $\begin{array}{c}5042507.9^{* *} \\
{[2.06]}\end{array}$ & Public enforcement & $\begin{array}{c}4927703.5^{* *} \\
{[2.07]}\end{array}$ & $\begin{array}{c}7134027.6^{* *} \\
{[2.31]}\end{array}$ & $\begin{array}{c}5089612.5^{* *} \\
{[2.07]}\end{array}$ & $\begin{array}{c}5319246.0^{* *} \\
{[2.16]}\end{array}$ \\
\hline Public enforcement & $\begin{array}{c}369610402.7 * * \\
{[2.50]} \\
-\end{array}$ & $\begin{array}{c}182852682.6^{*} \\
* \\
{[2.19]}\end{array}$ & $\begin{array}{c}373159491.8^{* *} \\
{[2.42]} \\
-\end{array}$ & $\begin{array}{c}357786365.5^{*} \\
* \\
{[2.20]} \\
-\end{array}$ & Public enforcement & $\begin{array}{c}379162166.7^{* *} \\
{[2.57]} \\
-\end{array}$ & $\begin{array}{c}189828297.7 * \\
* \\
{[2.30]}\end{array}$ & $\begin{array}{c}387942196.3^{* *} \\
{[2.53]} \\
-\end{array}$ & $\begin{array}{c}372331678.0^{*} \\
* \\
{[2.31]} \\
-\end{array}$ \\
\hline $\begin{array}{l}\text { Efficiency of the } \\
\text { Judiciary }\end{array}$ & $\begin{array}{c}147373465.3^{* *} \\
* \\
{[-2.74]}\end{array}$ & $\begin{array}{c}-75787478.1^{* *} \\
{[-2.18]}\end{array}$ & $\begin{array}{c}147111990.6 * * \\
* \\
{[-2.67]}\end{array}$ & $\begin{array}{c}141272301.2 * \\
* \\
{[-2.32]}\end{array}$ & $\begin{array}{l}\text { Efficiency of the } \\
\text { Judiciary }\end{array}$ & $\begin{array}{c}148422531.7 * * \\
* \\
{[-2.74]}\end{array}$ & $\begin{array}{c}- \\
76106928.6^{* *} \\
{[-2.18]}\end{array}$ & $\begin{array}{c}150686222.8^{* *} \\
* \\
{[-2.74]}\end{array}$ & $\begin{array}{c}145255925.7^{*} \\
* \\
{[-2.40]}\end{array}$ \\
\hline Rule of Law & $\begin{array}{c}47731863.2 \\
{[0.79]}\end{array}$ & $\begin{array}{c}2504187.4 \\
{[0.05]}\end{array}$ & $\begin{array}{c}55407454.4 \\
{[0.81]}\end{array}$ & $\begin{array}{c}51757828.4 \\
{[0.83]}\end{array}$ & Rule of Law & $\begin{array}{c}67083411.9 \\
{[1.21]}\end{array}$ & $\begin{array}{c}21700794.4 \\
{[0.43]}\end{array}$ & $\begin{array}{c}68174534.8 \\
{[1.07]}\end{array}$ & $\begin{array}{c}65022135.7 \\
{[1.13]}\end{array}$ \\
\hline $\begin{array}{l}\text { Microstructure } \\
\text { Control Variables } \\
\end{array}$ & & & & & $\begin{array}{l}\text { Microstructure } \\
\text { Control Variables } \\
\end{array}$ & & & & \\
\hline $\begin{array}{l}\text { Log Market } \\
\text { Capitalization }\end{array}$ & $\begin{array}{c}13683738.2 \\
{[1.62]}\end{array}$ & $\begin{array}{c}13789626.9^{*} \\
{[1.72]}\end{array}$ & $\begin{array}{c}13100962.3 \\
{[1.50]}\end{array}$ & $\begin{array}{c}13126798.5 \\
{[1.58]}\end{array}$ & $\begin{array}{l}\text { Log Market } \\
\text { Capitalization }\end{array}$ & $\begin{array}{c}15474441.0^{*} \\
{[1.83]}\end{array}$ & $\begin{array}{c}15610637.6^{*} \\
{[1.92]}\end{array}$ & $\begin{array}{c}14945043.3^{*} \\
{[1.69]}\end{array}$ & $\begin{array}{c}15047963.6^{*} \\
{[1.76]}\end{array}$ \\
\hline Log Trading Volume & $\begin{array}{c}-97553900.9 * * \\
{[-1.97]}\end{array}$ & $\begin{array}{c}-98510939.4^{*} \\
{[-1.88]}\end{array}$ & $\begin{array}{c}-100088489.0^{*} \\
{[-1.94]}\end{array}$ & $\begin{array}{c}- \\
100367040.7^{*} \\
{[-1.81]}\end{array}$ & Log Trading Volume & $\begin{array}{c}- \\
100535832.5^{* *} \\
{[-2.01]}\end{array}$ & $\begin{array}{c}102063839.0^{*} \\
{[-1.94]}\end{array}$ & $\begin{array}{c}104047378.5^{* *} \\
{[-2.01]}\end{array}$ & $\begin{array}{c}105638872.2^{*} \\
{[-1.92]}\end{array}$ \\
\hline Log Number of Trades & $\begin{array}{c}107927948.2 * \\
{[1.95]}\end{array}$ & $\begin{array}{c}108861573.6^{*} \\
{[1.86]}\end{array}$ & $\begin{array}{c}110492953.7^{*} \\
{[1.90]}\end{array}$ & $\begin{array}{c}110774776.8^{*} \\
{[1.78]}\end{array}$ & Log Number of Trades & $\begin{array}{c}108128686.1^{*} \\
{[1.94]}\end{array}$ & $\begin{array}{c}109680402.3 * \\
{[1.87]}\end{array}$ & $\begin{array}{c}111976964.3^{*} \\
{[1.93]}\end{array}$ & $\begin{array}{c}113676793.9^{*} \\
{[1.83]}\end{array}$ \\
\hline $\begin{array}{l}\text { Log Average Market } \\
\text { Trade Size }\end{array}$ & $\begin{array}{c}40473182.4 \\
{[1.54]}\end{array}$ & $\begin{array}{c}41262312.4 \\
{[1.44]}\end{array}$ & $\begin{array}{c}39674904.3 \\
\quad[1.47]\end{array}$ & $\begin{array}{c}39900686.5 \\
{[1.34]}\end{array}$ & $\begin{array}{l}\text { Log Average Market } \\
\text { Trade Size }\end{array}$ & $\begin{array}{c}48665515.1 * * \\
{[2.02]}\end{array}$ & $\begin{array}{c}49797406.6^{*} \\
{[1.91]}\end{array}$ & $\begin{array}{c}48884567.7 * * \\
{[1.99]}\end{array}$ & $\begin{array}{c}50003827.3^{*} \\
{[1.87]}\end{array}$ \\
\hline Log Market Volatility & $\begin{array}{c}6063559.9 \\
{[1.31]}\end{array}$ & $\begin{array}{c}6051786.7 \\
{[1.30]}\end{array}$ & $\begin{array}{c}6608081.1 \\
{[1.36]}\end{array}$ & $\begin{array}{c}6599694.9 \\
{[1.36]}\end{array}$ & Log Market Volatility & $\begin{array}{c}4949755.0 \\
{[0.97]}\end{array}$ & $\begin{array}{c}4943380.5 \\
{[0.97]}\end{array}$ & $\begin{array}{c}5112396.7 \\
{[0.95]}\end{array}$ & $\begin{array}{c}5054072.9 \\
{[0.94]}\end{array}$ \\
\hline $\begin{array}{l}\text { Country Control } \\
\text { Variables } \\
\end{array}$ & & & & & $\begin{array}{l}\text { Country Control } \\
\text { Variables } \\
\end{array}$ & & & & \\
\hline Log GDP per capita & $\begin{array}{c}-3273155.8 \\
{[-0.04]}\end{array}$ & $\begin{array}{c}-4568574.2 \\
{[-0.06]}\end{array}$ & $\begin{array}{c}-12295430.9 \\
{[-0.13]}\end{array}$ & $\begin{array}{c}-12471202.5 \\
{[-0.14]}\end{array}$ & Log GDP per capita & $\begin{array}{c}-35504442.9 \\
{[-0.50]}\end{array}$ & $\begin{array}{c}-36968380.1 \\
{[-0.53]}\end{array}$ & $\begin{array}{c}-35789254.9 \\
{[-0.43]}\end{array}$ & $\begin{array}{c}-36037082.8 \\
{[-0.44]}\end{array}$ \\
\hline Observation & 1972 & 1972 & 1768 & 1768 & Observations & 1972 & 1972 & 1768 & 1768 \\
\hline R-squared & 0.062 & 0.062 & 0.061 & 0.061 & R-squared & 0.062 & 0.062 & 0.060 & 0.060 \\
\hline
\end{tabular}




\begin{tabular}{|c|c|c|c|c|c|c|c|c|c|}
\hline \multicolumn{10}{|c|}{ Panel A2: Suspected Dislocating the EOD Price Case (Matched with option expiry date) } \\
\hline & Model 5 & Model 6 & Model 7 & Model 8 & & Model 5 & Model 6 & Model 7 & Model 8 \\
\hline & $\begin{array}{c}\text { Public } \\
\text { Enforcements } \\
\end{array}$ & All Jointly & Without US & Without US & & $\begin{array}{c}\text { Public } \\
\text { Enforcements }\end{array}$ & All Jointly & Without US & Without US \\
\hline Constant & $\begin{array}{c}29.76^{* *} \\
{[2.43]}\end{array}$ & $\begin{array}{l}29.53^{*} \\
{[1.81]}\end{array}$ & $\begin{array}{c}34.00^{* * *} \\
{[2.61]}\end{array}$ & $\begin{array}{c}34.44 * * * \\
{[2.71]}\end{array}$ & Constant & $\begin{array}{l}-10.52 \\
{[-0.64]}\end{array}$ & $\begin{array}{l}-16.75 \\
{[-0.77]}\end{array}$ & $\begin{array}{l}-8.184 \\
{[-0.48]}\end{array}$ & $\begin{array}{l}-9.880 \\
{[-0.55]}\end{array}$ \\
\hline $\begin{array}{l}\text { HFT Dummy } \\
\text { Law/Legal Index }\end{array}$ & \multirow[t]{2}{*}{$\begin{array}{c}-1.951^{*} \\
{[-1.81]}\end{array}$} & $\begin{array}{l}-2.144^{*} \\
{[-1.88]}\end{array}$ & \multirow[t]{2}{*}{$\begin{array}{c}-2.671^{* *} \\
{[-2.25]}\end{array}$} & $\begin{array}{c}-2.944 * * \\
{[-2.32]}\end{array}$ & $\begin{array}{l}\text { Co-Location Dummy } \\
\text { Law/Legal Index }\end{array}$ & \multirow[t]{2}{*}{$\begin{array}{l}0.574 \\
{[1.30]}\end{array}$} & $\begin{array}{l}0.602 \\
{[1.37]}\end{array}$ & \multirow[t]{2}{*}{$\begin{array}{l}0.608 \\
{[1.61]}\end{array}$} & $\begin{array}{l}0.597 \\
{[1.57]}\end{array}$ \\
\hline $\begin{array}{l}\text { Total Trading Rule Index } \\
\text { Surveillance }\end{array}$ & & $\begin{array}{c}-0.150 * * * \\
{[-2.64]} \\
0.0228 \\
{[0.14]}\end{array}$ & & $\begin{array}{c}-0.169 * * * \\
{[-2.77]} \\
0.0373 \\
{[1.13]}\end{array}$ & $\begin{array}{l}\text { Total Trading Rule Index } \\
\text { Surveillance }\end{array}$ & & $\begin{array}{c}0.0477 \\
{[1.29]} \\
0.135 \\
{[0.80]}\end{array}$ & & $\begin{array}{c}0.0431 \\
{[1.10]} \\
-0.0150 \\
{[-0.66]}\end{array}$ \\
\hline Public enforcement & $\begin{array}{c}-0.179 * \\
{[-1.86]}\end{array}$ & $\begin{array}{c}-0.174^{*} \\
{[-1.68]}\end{array}$ & $\begin{array}{c}-0.177^{*} \\
{[-1.81]}\end{array}$ & $\begin{array}{c}-0.170^{*} \\
{[-1.82]}\end{array}$ & Public enforcement & $\begin{array}{r}-0.0707 \\
{[-1.04]}\end{array}$ & $\begin{array}{c}-0.0414 \\
{[-0.55]}\end{array}$ & $\begin{array}{c}-0.0568 \\
{[-0.84]}\end{array}$ & $\begin{array}{r}-0.0573 \\
{[-0.89]}\end{array}$ \\
\hline Public enforcement & $\begin{array}{c}-10.98 * * * \\
{[-2.77]}\end{array}$ & $\begin{array}{c}-10.65 * * * \\
{[-4.70]}\end{array}$ & $\begin{array}{c}-11.92 * * * \\
{[-2.78]}\end{array}$ & $\begin{array}{c}-11.85^{* * *} \\
{[-2.60]}\end{array}$ & Public enforcement & $\begin{array}{l}0.0166 \\
{[0.00]}\end{array}$ & $\begin{array}{l}-2.183 \\
{[-1.09]}\end{array}$ & $\begin{array}{l}0.0552 \\
{[0.01]}\end{array}$ & $\begin{array}{l}0.490 \\
{[0.10]}\end{array}$ \\
\hline Efficiency of the Judiciary & $\begin{array}{l}2.515^{*} \\
{[1.80]}\end{array}$ & $\begin{array}{c}2.832^{* *} \\
{[1.98]}\end{array}$ & $\begin{array}{l}2.828^{*} \\
{[1.91]}\end{array}$ & $\begin{array}{l}3.335^{*} \\
{[1.95]}\end{array}$ & Efficiency of the Judiciary & $\begin{array}{l}0.886 \\
{[0.84]}\end{array}$ & $\begin{array}{l}1.679 \\
{[1.55]}\end{array}$ & $\begin{array}{l}0.991 \\
{[0.90]}\end{array}$ & $\begin{array}{l}0.773 \\
{[0.66]}\end{array}$ \\
\hline Rule of Law & $\begin{array}{l}-1.915 \\
{[-1.20]}\end{array}$ & $\begin{array}{l}-2.577 \\
{[-1.14]}\end{array}$ & $\begin{array}{l}-0.894 \\
{[-0.54]}\end{array}$ & $\begin{array}{l}-1.451 \\
{[-0.87]}\end{array}$ & Rule of Law & $\begin{array}{l}0.531 \\
{[0.35]}\end{array}$ & $\begin{array}{l}0.149 \\
{[0.07]}\end{array}$ & $\begin{array}{l}1.611 \\
{[0.97]}\end{array}$ & $\begin{array}{l}1.783 \\
{[1.10]}\end{array}$ \\
\hline $\begin{array}{l}\text { Microstructure Control } \\
\text { Variables }\end{array}$ & & & & & $\begin{array}{l}\text { Microstructure Control } \\
\text { Variables }\end{array}$ & & & & \\
\hline Log Market Capitalization & $\begin{array}{c}0.453^{* *} \\
{[2.21]}\end{array}$ & $\begin{array}{l}0.359^{*} \\
{[1.77]}\end{array}$ & $\begin{array}{l}0.375^{*} \\
{[1.85]}\end{array}$ & $\begin{array}{l}0.268 \\
{[1.34]}\end{array}$ & Log Market Capitalization & $\begin{array}{l}0.208 \\
{[1.03]}\end{array}$ & $\begin{array}{l}0.221 \\
{[1.10]}\end{array}$ & $\begin{array}{l}0.154 \\
{[0.74]}\end{array}$ & $\begin{array}{l}0.163 \\
{[0.79]}\end{array}$ \\
\hline Log Trading Volume & $\begin{array}{l}3.085^{*} \\
{[1.96]}\end{array}$ & $\begin{array}{c}3.367^{* *} \\
{[2.08]}\end{array}$ & $\begin{array}{c}3.440^{* *} \\
{[2.06]}\end{array}$ & $\begin{array}{c}3.792 * * \\
{[2.20]}\end{array}$ & Log Trading Volume & $\begin{array}{l}1.112 \\
{[0.81]}\end{array}$ & $\begin{array}{l}0.966 \\
{[0.70]}\end{array}$ & $\begin{array}{l}1.218 \\
{[0.85]}\end{array}$ & $\begin{array}{l}1.079 \\
{[0.75]}\end{array}$ \\
\hline Log Number of Trades & $\begin{array}{c}-4.129 * * \\
{[-2.47]}\end{array}$ & $\begin{array}{c}-4.238^{* *} \\
{[-2.51]}\end{array}$ & $\begin{array}{c}-4.284 * * \\
{[-2.44]}\end{array}$ & $\begin{array}{c}-4.443 * * \\
{[-2.49]}\end{array}$ & Log Number of Trades & $\begin{array}{l}-0.945 \\
{[-0.68]}\end{array}$ & $\begin{array}{l}-0.797 \\
{[-0.57]}\end{array}$ & $\begin{array}{l}-0.847 \\
{[-0.58]}\end{array}$ & $\begin{array}{l}-0.698 \\
{[-0.47]}\end{array}$ \\
\hline $\begin{array}{l}\text { Log Average Market Trade } \\
\text { Size }\end{array}$ & $\begin{array}{l}-1.015 \\
{[-1.04]}\end{array}$ & $\begin{array}{l}-1.305 \\
{[-1.33]}\end{array}$ & $\begin{array}{l}-1.555 \\
{[-1.53]}\end{array}$ & $\begin{array}{c}-1.909^{*} \\
{[-1.84]}\end{array}$ & $\begin{array}{l}\text { Log Average Market Trade } \\
\text { Size }\end{array}$ & $\begin{array}{l}0.386 \\
{[0.34]}\end{array}$ & $\begin{array}{l}0.494 \\
{[0.41]}\end{array}$ & $\begin{array}{l}0.129 \\
{[0.11]}\end{array}$ & $\begin{array}{l}0.227 \\
{[0.19]}\end{array}$ \\
\hline $\begin{array}{l}\text { Log Market Volatility } \\
\text { Country Control Variables }\end{array}$ & $\begin{array}{l}0.233 \\
{[1.15]}\end{array}$ & $\begin{array}{l}0.258 \\
{[1.22]}\end{array}$ & $\begin{array}{l}0.332 \\
{[1.62]}\end{array}$ & $\begin{array}{l}0.371^{*} \\
{[1.71]}\end{array}$ & $\begin{array}{l}\text { Log Market Volatility } \\
\text { Country Control Variables }\end{array}$ & $\begin{array}{l}0.421^{*} \\
{[1.94]}\end{array}$ & $\begin{array}{l}0.420^{*} \\
{[1.93]}\end{array}$ & $\begin{array}{c}0.508^{* *} \\
{[2.35]}\end{array}$ & $\begin{array}{c}0.503 * * \\
{[2.33]}\end{array}$ \\
\hline Log GDP per capita & $\begin{array}{l}1.143 \\
{[0.53]}\end{array}$ & $\begin{array}{l}1.739 \\
{[0.79]}\end{array}$ & $\begin{array}{r}-0.0226 \\
{[-0.01]}\end{array}$ & $\begin{array}{l}0.332 \\
{[0.15]}\end{array}$ & Log GDP per capita & $\begin{array}{l}1972 \\
0.093\end{array}$ & $\begin{array}{l}1972 \\
0.094\end{array}$ & $\begin{array}{l}1768 \\
0.081\end{array}$ & $\begin{array}{l}1768 \\
0.081\end{array}$ \\
\hline Observations & 1972 & 1972 & 1768 & 1768 & Observations & 1972 & 1972 & 1768 & 1768 \\
\hline R-squared & 0.066 & 0.069 & 0.053 & 0.057 & $\mathrm{R}$-squared & 0.093 & 0.094 & 0.081 & 0.081 \\
\hline
\end{tabular}




\begin{tabular}{|c|c|c|c|c|c|c|c|c|c|}
\hline & Model 5 & Model 6 & Model 7 & Model 8 & & Model 5 & Model 6 & Model 7 & Model 8 \\
\hline & $\begin{array}{c}\text { Public } \\
\text { Enforcements } \\
\end{array}$ & All Jointly & Without US & Without US & & $\begin{array}{c}\text { Public } \\
\text { Enforcements }\end{array}$ & All Jointly & Without US & Without US \\
\hline Constant & $\begin{array}{c}- \\
103172001.0 * * \\
* \\
{[-3.83]}\end{array}$ & $\begin{array}{c}- \\
103452797.9^{* *} \\
* \\
{[-3.64]}\end{array}$ & $\begin{array}{c}- \\
111253413.9 * * \\
* \\
{[-3.82]}\end{array}$ & $\begin{array}{c}- \\
105578733.8^{* *} \\
* \\
{[-3.65]}\end{array}$ & Constant & $\begin{array}{c}- \\
95655429.8^{* *} \\
* \\
{[-3.69]}\end{array}$ & $\begin{array}{c}- \\
98624927.1 * * \\
* \\
{[-3.54]}\end{array}$ & $\begin{array}{c}- \\
105967046.3 * * \\
* \\
{[-3.71]}\end{array}$ & $\begin{array}{c}- \\
102988961.8 * * \\
* \\
{[-3.58]}\end{array}$ \\
\hline $\begin{array}{l}\text { HFT Dummy } \\
\text { Law/Legal Index }\end{array}$ & $\begin{array}{c}-4188307.1^{* *} \\
{[-2.53]}\end{array}$ & $\begin{array}{c}-4027920.0^{* *} \\
{[-2.43]}\end{array}$ & $\begin{array}{c}-4074299.7^{* *} \\
{[-2.47]}\end{array}$ & $\begin{array}{c}-3802581.1^{* *} \\
{[-2.31]}\end{array}$ & $\begin{array}{l}\text { Co-Location Dummy } \\
\text { Law/Legal Index }\end{array}$ & $\begin{array}{c}184807.0 \\
{[0.35]}\end{array}$ & $\begin{array}{c}261361.3 \\
{[0.48]}\end{array}$ & $\begin{array}{c}-571114.6 \\
{[-0.96]}\end{array}$ & $\begin{array}{c}-614968.2 \\
{[-1.03]}\end{array}$ \\
\hline $\begin{array}{l}\text { Total Trading Rule } \\
\text { Index }\end{array}$ & & $\begin{array}{c}97967.4 * * \\
{[2.52]}\end{array}$ & & $\begin{array}{c}131708.1^{* * *} \\
{[2.74]}\end{array}$ & $\begin{array}{l}\text { Total Trading Rule } \\
\text { Index }\end{array}$ & & $\begin{array}{c}129486.8 * * * \\
{[3.15]}\end{array}$ & & $\begin{array}{c}167980.6^{* * * *} \\
{[3.33]}\end{array}$ \\
\hline Surveillance & & $\begin{array}{c}-106504.1 \\
{[-1.07]}\end{array}$ & & $\begin{array}{c}-375547.0 * * * \\
{[-4.07]}\end{array}$ & Surveillance & & $\begin{array}{c}-72385.6 \\
{[-0.71]}\end{array}$ & & $\begin{array}{c}-360420.8^{* * * *} \\
{[-4.01]}\end{array}$ \\
\hline Public enforcement & $\begin{array}{c}41891.2 \\
{[0.90]}\end{array}$ & $\begin{array}{c}27404.1 \\
{[0.46]}\end{array}$ & $\begin{array}{c}47854.2 \\
{[0.99]}\end{array}$ & $\begin{array}{c}-15778.2 \\
{[-0.28]}\end{array}$ & Public enforcement & $\begin{array}{c}84370.1^{*} \\
{[1.93]}\end{array}$ & $\begin{array}{c}77212.3 \\
{[1.32]}\end{array}$ & $\begin{array}{c}84176.4^{*} \\
{[1.88]}\end{array}$ & $\begin{array}{c}22723.8 \\
{[0.46]}\end{array}$ \\
\hline Public enforcement & $\begin{array}{c}2743201.5 \\
{[0.59]}\end{array}$ & $\begin{array}{c}4916601.0 \\
{[1.36]}\end{array}$ & $\begin{array}{c}3677889.6 \\
{[0.75]}\end{array}$ & $\begin{array}{c}10826535.1^{* *} \\
{[2.15]}\end{array}$ & Public enforcement & $\begin{array}{c}4260655.1 \\
{[0.92]}\end{array}$ & $\begin{array}{c}5887813.0^{*} \\
{[1.67]}\end{array}$ & $\begin{array}{c}5364271.0 \\
{[1.12]}\end{array}$ & $\begin{array}{c}12277921.9 * * \\
{[2.44]}\end{array}$ \\
\hline $\begin{array}{l}\text { Efficiency of the } \\
\text { Judiciary }\end{array}$ & $\begin{array}{c}-1198518.9 \\
{[-0.86]}\end{array}$ & $\begin{array}{c}-2132677.3^{* *} \\
{[-2.30]}\end{array}$ & $\begin{array}{c}-1592649.9 \\
{[-1.09]}\end{array}$ & $\begin{array}{c}-4475182.0 * * * \\
{[-2.93]}\end{array}$ & $\begin{array}{l}\text { Efficiency of the } \\
\text { Judiciary }\end{array}$ & $\begin{array}{c}-1464032.6 \\
{[-1.03]}\end{array}$ & $\begin{array}{c}-2234717.5^{* *} \\
{[-2.39]}\end{array}$ & $\begin{array}{c}-1941223.8 \\
{[-1.32]}\end{array}$ & $\begin{array}{c}-4799221.5^{* * *} \\
{[-3.07]}\end{array}$ \\
\hline Rule of Law & $\begin{array}{c}-4561445.3^{*} \\
{[-1.94]}\end{array}$ & $\begin{array}{c}-3608952.1 \\
{[-1.52]}\end{array}$ & $\begin{array}{c}-5750568.0 * * \\
{[-2.14]}\end{array}$ & $\begin{array}{c}-3673614.0 \\
{[-1.49]}\end{array}$ & Rule of Law & $\begin{array}{c}-2304614.6 \\
{[-1.44]}\end{array}$ & $\begin{array}{c}-1451187.8 \\
{[-0.87]}\end{array}$ & $\begin{array}{c}-4019356.2 * \\
{[-1.90]}\end{array}$ & $\begin{array}{c}-2049534.2 \\
{[-1.09]}\end{array}$ \\
\hline $\begin{array}{l}\text { Microstructure } \\
\text { Control Variables }\end{array}$ & & & & & $\begin{array}{l}\text { Microstructure } \\
\text { Control Variables } \\
\end{array}$ & & & & \\
\hline $\begin{array}{l}\text { Log Market } \\
\text { Capitalization }\end{array}$ & $\begin{array}{c}1566533.3 * * \\
{[2.18]}\end{array}$ & $\begin{array}{c}1601592.5^{* *} \\
{[2.19]}\end{array}$ & $\begin{array}{c}1536220.6^{* *} \\
{[2.14]}\end{array}$ & $\begin{array}{c}1580067.4^{* *} \\
{[2.17]}\end{array}$ & $\begin{array}{l}\text { Log Market } \\
\text { Capitalization }\end{array}$ & $\begin{array}{c}1811021.6^{* *} \\
{[2.42]}\end{array}$ & $\begin{array}{c}1846344.0^{* *} \\
{[2.44]}\end{array}$ & $\begin{array}{c}1759119.4^{* *} \\
{[2.38]}\end{array}$ & $\begin{array}{c}1794199.4^{* *} \\
{[2.40]}\end{array}$ \\
\hline Log Trading Volume & $\begin{array}{c}236482.9 \\
{[0.37]}\end{array}$ & $\begin{array}{c}-80387.6 \\
{[-0.12]}\end{array}$ & $\begin{array}{c}138900.2 \\
{[0.22]}\end{array}$ & $\begin{array}{c}-333831.4 \\
{[-0.48]}\end{array}$ & Log Trading Volume & $\begin{array}{c}-378450.1 \\
{[-0.63]}\end{array}$ & $\begin{array}{c}-774736.2 \\
{[-1.21]}\end{array}$ & $\begin{array}{c}-459036.4 \\
{[-0.73]}\end{array}$ & $\begin{array}{c}-1001491.4 \\
{[-1.47]}\end{array}$ \\
\hline Log Number of Trades & $\begin{array}{c}948176.8 \\
{[1.08]}\end{array}$ & $\begin{array}{c}1257295.3 \\
{[1.37]}\end{array}$ & $\begin{array}{c}1209211.1 \\
{[1.31]}\end{array}$ & $\begin{array}{c}1687494.7^{*} \\
{[1.71]}\end{array}$ & Log Number of Trades & $\begin{array}{c}1218873.1 \\
{[1.45]}\end{array}$ & $\begin{array}{c}1621308.3^{*} \\
{[1.84]}\end{array}$ & $\begin{array}{c}1493774.6^{*} \\
{[1.68]}\end{array}$ & $\begin{array}{c}2073155.6^{* *} \\
{[2.19]}\end{array}$ \\
\hline $\begin{array}{l}\text { Log Average Market } \\
\text { Trade Size }\end{array}$ & $\begin{array}{c}-1540901.2 * * * \\
{[-2.87]}\end{array}$ & $\begin{array}{c}-1279624.4^{* *} \\
{[-2.42]}\end{array}$ & $\begin{array}{c}-1501727.6^{* * *} \\
{[-2.87]}\end{array}$ & $\begin{array}{c}-1118551.3^{* *} \\
{[-2.20]}\end{array}$ & $\begin{array}{l}\text { Log Average Market } \\
\text { Trade Size }\end{array}$ & $\begin{array}{c}-353686.5 \\
{[-1.23]}\end{array}$ & $\begin{array}{c}-60132.2 \\
{[-0.21]}\end{array}$ & $\begin{array}{c}-364850.9 \\
{[-1.18]}\end{array}$ & $\begin{array}{c}16644.9 \\
{[0.06]}\end{array}$ \\
\hline Log Market Volatility & $\begin{array}{c}669041.6 \\
{[1.30]}\end{array}$ & $\begin{array}{c}665143.6 \\
{[1.30]}\end{array}$ & $\begin{array}{c}642496.1 \\
{[1.24]}\end{array}$ & $\begin{array}{c}628264.0 \\
{[1.23]}\end{array}$ & Log Market Volatility & $\begin{array}{c}683389.0 \\
{[1.30]}\end{array}$ & $\begin{array}{c}681735.8 \\
{[1.31]}\end{array}$ & $\begin{array}{c}603221.5 \\
{[1.14]}\end{array}$ & $\begin{array}{c}583342.1 \\
{[1.13]}\end{array}$ \\
\hline $\begin{array}{l}\text { Country Control } \\
\text { Variables } \\
\end{array}$ & & & & & $\begin{array}{l}\text { Country Control } \\
\text { Variables } \\
\end{array}$ & & & & \\
\hline Log GDP per capita & $\begin{array}{c}9427670.2 * * * \\
{[2.59]}\end{array}$ & $\begin{array}{c}8998763.9^{* *} \\
{[2.50]}\end{array}$ & $\begin{array}{c}11099040.5^{* * * *} \\
{[2.68]}\end{array}$ & $\begin{array}{c}10800737.5^{* * * *} \\
{[2.63]}\end{array}$ & Log GDP per capita & $\begin{array}{c}5575928.1^{* *} \\
{[2.37]}\end{array}$ & $\begin{array}{c}5196258.3^{* *} \\
{[2.27]}\end{array}$ & $\begin{array}{c}8027994.0^{* *} \\
{[2.57]}\end{array}$ & $\begin{array}{c}7943522.7 * * \\
{[2.56]}\end{array}$ \\
\hline Observations & 1972 & 1972 & 1768 & 1768 & Obse & 1972 & 1972 & 1768 & 1768 \\
\hline R-squared & 0.165 & 0.166 & 0.166 & 0.168 & R-squared & 0.157 & 0.159 & 0.159 & 0.162 \\
\hline
\end{tabular}

